University of Nebraska - Lincoln

DigitalCommons@University of Nebraska - Lincoln

\title{
Quaternary Sedimentation and Subsidence History of Lake Baikal, Siberia, Based on Seismic Stratigraphy and Coring
}

S.M. Colman

U.S. Geological Survey, 384 Woods Hole Rd., Woods Hole, Massachusetts 02543 U.S.A.

E.B. Karabanov

Department of Geosciences, University of South Carolina, Columbia, South Carolina 29209 U.S.A.

C.H. Nelson, III

Instituto Andaluz de Ciencias de la Tierra, C.S.I.C./Universidad de Granada Facultad de Ciencias, Campus de Fuentenueva, s/n, 18002 Granada, Spain

Follow this and additional works at: https://digitalcommons.unl.edu/usgsstaffpub

Part of the Earth Sciences Commons

Colman, S.M.; Karabanov, E.B.; and Nelson, III, C.H., "Quaternary Sedimentation and Subsidence History of Lake Baikal, Siberia, Based on Seismic Stratigraphy and Coring" (2003). USGS Staff -- Published Research. 279.

https://digitalcommons.unl.edu/usgsstaffpub/279

This Article is brought to you for free and open access by the US Geological Survey at DigitalCommons@University of Nebraska - Lincoln. It has been accepted for inclusion in USGS Staff -- Published Research by an authorized administrator of DigitalCommons@University of Nebraska - Lincoln. 


\title{
QUATERNARY SEDIMENTATION AND SUBSIDENCE HISTORY OF LAKE BAIKAL, SIBERIA, BASED ON SEISMIC STRATIGRAPHY AND CORING
}

\author{
S.M. COLMAN, ${ }^{1}$ E.B. KARABANOV,${ }^{2}$ AND C.H. NELSON, III ${ }^{3}$ \\ ${ }^{1}$ U.S. Geological Survey, 384 Woods Hole Rd., Woods Hole, Massachusetts 02543 U.S.A. \\ e-mail:scolman@usgs.gov \\ ${ }^{2}$ Department of Geosciences, University of South Carolina, Columbia, South Carolina 29209 U.S.A. \\ ${ }^{3}$ Instituto Andaluz de Ciencias de la Tierra, C.S.I.C./Universidad de Granada Facultad de Ciencias, Campus de Fuentenueva, s/n, 18002 Granada, Spain
}

Aвstract: The long, continuous, high-latitude, stratigraphic record of Lake Baikal was deposited in three broad sedimentary environments, defined by high-resolution seismic-reflection and coring methods: (1) turbidite depositional systems, by far the most widespread, characterizing most of the margins and floors of the main basins of the lake, (2) large deltas of major drainages, and (3) tectonically or topographically isolated ridges and banks. Holocene sedimentation rates based on radiocarbon ages vary by more than an order of magnitude among these environments, from less than about $0.03 \mathrm{~mm} / \mathrm{yr}$ on ridges and banks to more than about $0.3 \mathrm{~mm} / \mathrm{yr}$ on basin floors. Extrapolating these rates, with a correction for compaction, yields tentative estimates of about 25 and 11 Ma for the inception of rifting in the Central and North basins, respectively, and less than 6 Ma for the 200-m sediment depth on Academician Ridge.

The Selenga Delta has the distinctive form of a classic prograding Gilbert-type delta, but its history appears to represent a complex combination of tectonism and sedimentation. The central part of the delta is underlain by prograding, shallow-water sequences, now several hundred meters below the lake surface. These deposits and much of the delta slope are mantled by fine-grained, deep-water, hemipelagic deposits whose base is estimated to be about $\mathbf{6 5 0 , 0 0 0}$ years old. Modern coarse-grained sediment bypasses the delta slope through fault-controlled canyons that feed large, subaqueous fans at the ends of the South and Central basins. These relations, along with abundant other evidence of recent faulting and the great depths of the Central and South basins, suggest that these two rift basins have experienced a period of unusually rapid subsidence over the last 650,000 years, during at least part of which sedimentation has failed to keep pace.

\section{INTRODUCTION}

\section{Setting}

Lake Baikal, the world's deepest (1637 m) and perhaps oldest lake, occupies an active continental rift in southeastern Siberia. The seismically active Baikal Rift Zone separates the Siberian Platform to the northwest from the Mongolian fold belt to the southeast (Logatchev and Florensov 1978; Hutchinson et al. 1992; Mats 1993; Moore et al. 1997; Mats et al. 2000). For many reasons, from its active tectonics to its highly endemic flora and fauna, Lake Baikal has attracted almost mystical attention from researchers, especially since the opening of the former Soviet Union to outside scientists in 1989.

Lake Baikal is segmented into three basins: North, Central, and South, about 900, 1600, and $1400 \mathrm{~m}$ deep, respectively (Fig. 1). The basins, each about $200 \mathrm{~km}$ long, are separated by fault-controlled accommodation zones that rise to depths of about $300 \mathrm{~m}$. Academician Ridge separates the North from the Central Basin, and a complex zone around the Buguldeika Saddle and the Selenga Delta separates the Central from the South Basin. All of the basins exhibit an asymmetric, half-graben morphology with steep border-fault margins on the northwestern side and more gradual, though still faulted, ramp margins on the southeastern side.

The geomorphology of the asymmetric basins and the high-relief border faults result in smaller drainages on the western sides of the basins and larger drainages entering the ramp and axial margins. Short, steep streams less than $20 \mathrm{~km}$ long feed numerous coarse-grained fan deltas and alluvial fans along the northwestern border-fault margin of the lake. Sediment feeds directly across narrow shelves (0-500 m wide) onto the steep basin slopes and accumulates in base-of-slope aprons (Nelson et al. 1995; Nelson et al. 1999). On the southeastern sides of the lake, shelves are wider (500-2000 $\mathrm{m}$ ), topographic relief reaches $2700 \mathrm{~m}$ in glaciated mountains, and longer rivers drain mountain valleys to feed sublacustrine fans on the basin floors. Several major rivers have built substantial deltas into the lake, of which the Selenga Delta, on the east margin between the Central and South basins, is the largest (Fig. 1). Other significant deltas include that of the Upper Angara River (Back et al. 1999), an axial drainage that enters the north end of the North Basin, and the Barguzin River, which enters the northeastern corner of the Central Basin.

\section{Importance of the Sedimentary Record of Lake Baikal}

The importance of the sedimentary record of Lake Baikal is difficult to overestimate. These sediments record the tectonic history of one of the most complex and active continental rift systems in the world. Rifting and related syndepositional processes have been active for a long time (probably since at least the mid-Miocene), and different parts of the rift have been active at different times (Logatchev and Florensov 1978; Hutchinson et al. 1992; Moore et al. 1997; Mats et al. 2000). This history, combined with continuing modern tectonism, reveals details of rift-forming processes (e.g., Agar and Klitgord 1995) that are seldom recorded in ancient, or even modern, rifts.

The deposits in Lake Baikal may also serve as analogs for deposits of ancient rift basins and the energy and mineral resources that they contain (e.g., Katz 1990). Rift-basin sedimentation patterns have generated a great deal of recent scientific interest (e.g., Olsen et al. 1996). The many factors that control rift sedimentation, and the variations in process rates, depositional facies, and sedimentary architecture, are all observable in the modern environment of Lake Baikal. Its relatively high latitude distinguishes it from the other large extant rift-lake basins, which are in East Africa (Scholz et al. 1998).

Lake Baikal sediments are also important paleoclimate archives because of their length and continuity, and because of the relatively high-latitude, highly seasonal climate (e.g., Peck et al. 1994; Colman et al. 1995; Williams et al. 1997).

\section{Purpose and Focus}

From 1990 to 1992, the U.S. Geological Survey, in cooperation with the Limnological Institute of the Russian Academy of Sciences in Irkutsk, the U.S. National Science Foundation, and the University of South Carolina, conducted three ship-based scientific expeditions on Lake Baikal, Siberia. These expeditions were part of a joint Russian-American project to obtain and decipher the paleoclimate record contained in the sediments of Lake Baikal (Lake Baikal Paleoclimate Project Members 1992). Data collection had two primary thrusts: (1) to obtain high-resolution seismic-reflection profiles of selected areas of the lake, and (2) to obtain sediment cores for paleoclimatic and paleolimnological analyses. The ship-based operations of 


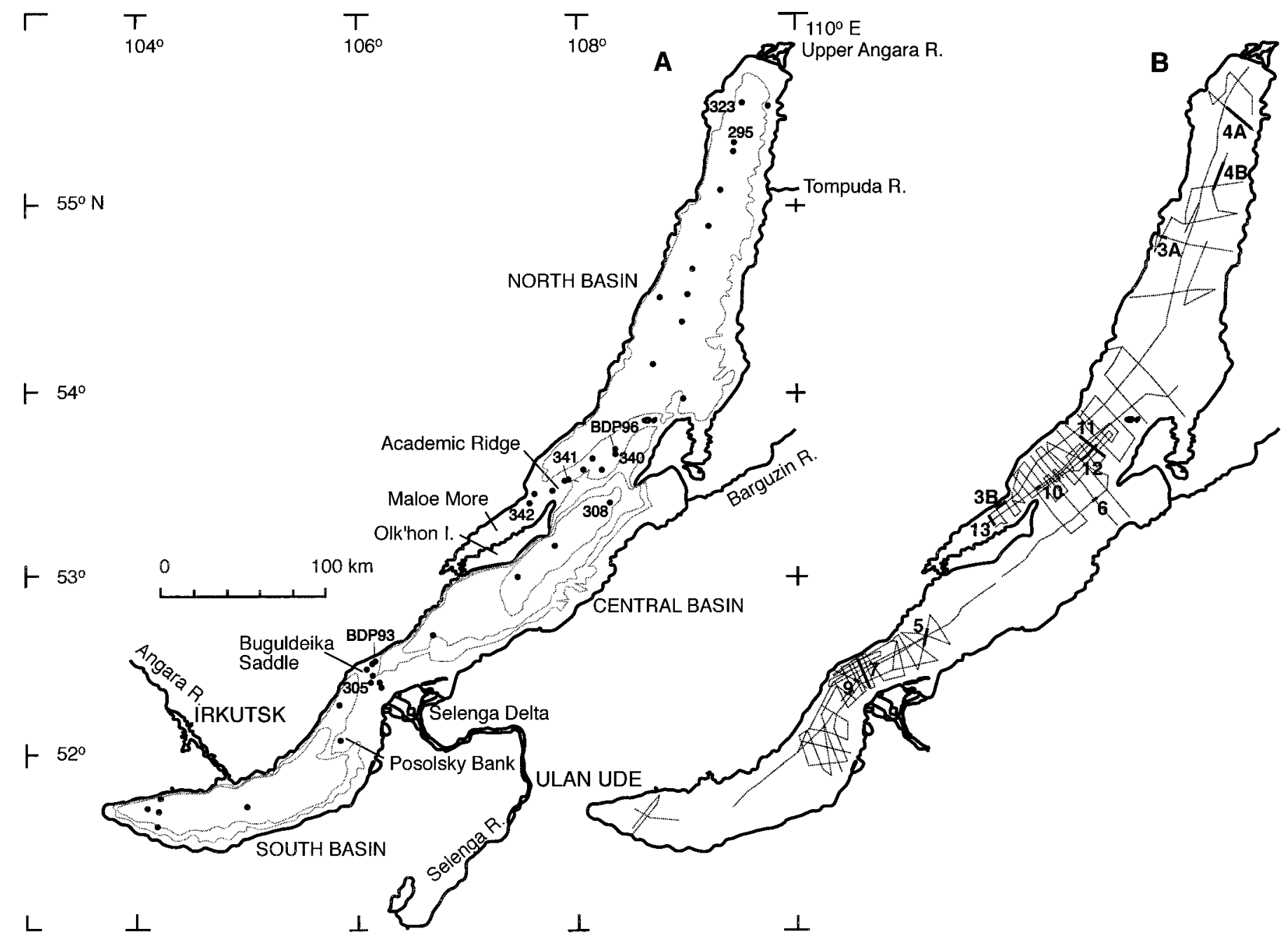

FIg. 1.-Location map of Lake Baikal showing A) bathymetry (500 m contour interval), geographic names, and core locations, and B) geophysical track lines. Heavy, labeled segments of tracklines are locations of seismic profiles shown in the figures indicated by the labels; locations of cores discussed in the text are numbered.

the Lake Baikal Paleoclimate Project were the first phase of Baikal Drilling Project (Kuzmin et al. 1993). The initial stage was followed by drilling of long cores from several sites. Basic descriptions and analytical data from the first two of the drill cores have been published and are included in the discussion here: (1) the 100-m drill hole near Buguldeika, across the lake from the Selenga Delta (BDP93; Fig. 1; BDP Members 1997a), and the 200-m drill hole on Academician Ridge (BDP96; Fig. 1; BDP Members 1997b). Information from the upper part of the 1998 drill hole on Academician Ridge (Antipin et al. 2001) is compatible with that from the nearby 1996 drill hole.

The basic seismic-reflection data and core descriptions from the 19901992 expeditions were made available in preliminary reports (Colman et al. 1994b; Colman et al. 1996a), but these data have not been synthesized with respect to sedimentary environments and processes in Lake Baikal. Some of the cores have been studied for paleoclimate proxies and chronology (e.g., Peck et al. 1994; Colman et al. 1995; Edgington et al. 1996; Williams et al. 1997; Kuzmin et al. 2000), but only limited use of the core and seismic-reflection data has been made for other purposes, such as description of selected turbidite depositional features (Nelson et al. 1999).

Here we synthesize the 1990-1992 seismic-reflection data and combine it with morphological data from published bathymetry and lithological data from cores of the Lake Baikal Paleoclimate Project (Lake Baikal Paleoclimate Project Members 1992) and the Baikal Drilling Project (Williams et al. 1992; Kuzmin et al. 1993; BDP Members 1997a, 1997b; Williams et al. 2001). Of particular importance in discussing sedimentary environments and processes are the published chronological data (e.g., Edgington et al. 1991, Edgington et al. 1996; Colman et al. 1996b; Williams et al. 1997). The purpose of this synthesis is an integrated examination of major sedimentary environments in Lake Baikal, the processes that formed them, and how they have changed over varying time intervals within the Quaternary.

\section{METHODS AND DATA}

\section{Seismic-Reflection Data}

We collected about $3600 \mathrm{~km}$ of high-resolution seismic-reflection profiles during the ship-based operations (Fig. 1B). Two basic seismic systems were used for most of the profiles: (1) a $3.5 \mathrm{kHz}$ system, which gave resolution of $<0.5 \mathrm{~m}$ and average sediment penetration of 30-50 m, and (2) a single-channel, $15 \mathrm{in}^{3}(255 \mathrm{ml})$ water-gun system, which gave resolution of less than a meter and average sediment penetration of 200-300 $\mathrm{m}$. The water-gun data were digitized from analog tape and processed to increase their quality. A detailed description of data collection and processing is given by Colman et al. 1994a. All of the digital water-gun data, image files of all of the profile lines, navigation data, location maps, descriptions of methods, and a discussion (in CD-ROM form) are also available (Colman et al. 1996a). 


\section{Coring, Sedimentology}

On the basis of seismic-reflection data, a variety of types of cores, including box, gravity, and piston cores, were collected in several sedimentary environments (Fig. 1). The core sites were focused on: (1) the prodelta area of the Selenga Delta; (2) Academician Ridge, and (3) the turbidite environments of basin floors and marginal fans. A total of 209 cores were collected at 38 sites during the three cruises (Fig. 1A).

Coring methods are described in detail by Colman et al. (1994b), who also provide basic descriptive core data, including visual core descriptions, photographs, X-radiographs, grain-size data, and measurements of water content and bulk density. A wide variety of sedimentological, geochemical, paleontological, and geochronological analyses were focused on specific cores from these environments. Similar methods were used for the drill cores (BDP Members 1997a, 1997b).

\section{Sedimentation Rates}

Sedimentation rates can be calculated from many types of age estimates, ranging from long-term rates derived from broad biostratigraphic age estimates (e.g., Mats 1993) to short-term rates derived from methods such as ${ }^{210} \mathrm{~Pb}$ and ${ }^{137} \mathrm{Cs}$ (Edgington et al. 1991). The former provide averages that are too general for our purposes. The latter provide accurate short-term mass-accumulation rates $\left(\mathrm{g} / \mathrm{cm}^{2} / \mathrm{yr}\right)$, but these rates are difficult to translate into longer-term sedimentation rates (e.g., $\mathrm{cm} / \mathrm{kyr}$ ) because they are derived from the uppermost, unconsolidated sediments (commonly greater than 70 weight percent water) and because rates for the last 50-150 years are difficult to extrapolate to depositional time scales of thousands of years.

For the time scales and sediment thicknesses of concern here, radiocarbon-based estimates of sedimentation rates are most appropriate. Radiocarbon analyses were obtained by accelerator-mass spectrometer methods on samples of total organic carbon, which consisted mostly of autochthonous carbon derived from algal material. Details of radiocarbon methods and results are discussed by Colman et al. (1996b). Sedimentation rates derived from the radiocarbon age estimates vary by more than an order of magnitude in different depositional settings in Lake Baikal.

\section{SEDIMENTARY ENVIRONMENTS}

Each of the three main basins of the lake (South, Central, and North) is characterized by a relatively flat basin floor, at least one very large, longitudinally fed, subaqueous fan leading into the basin from a large delta, and a variety of smaller, laterally fed, subaqueous fans and aprons (Fig. 2). These basins floors and associated fans occupy by far the largest area of any of the depositional environments in the lake. Of several large deltas built into the lake, only the most prominent-the Selenga Delta-is discussed here. Finally, several bathymetric highs rise above the surrounding lake floor, forming environments isolated from direct river or turbidite input. Academician Ridge, separating the North from the Central Basin, is the most prominent of these highs, but others exist, such as Posolsky Bank.

\section{Basin Floors and Subaqueous Fans}

Basin floors and subaqueous fans are part of large, active turbidite systems in Lake Baikal, as described by Nelson et al. (1995) and Nelson et al. (1999), primarily from $3.5 \mathrm{kHz}$ seismic profiles and core data. Here, we summarize those descriptions of turbidite systems and combine them with observations from the water-gun seismic profiles, focusing on the North Basin and the subaqueous fans at the foot of the Selenga Delta.

Sediments underlying basin floors and marginal fans typically consist of an upper diatomaceous, fine-grained hemipelagic mud that is interbedded with coarse silt or mud turbidite layers. This upper unit has relatively high, but variable, contents of diatoms, biogenic silica, and total organic carbon. It was deposited during postglacial times, since about 13,000 years ago
(Carter and Colman 1994; Colman et al. 1996b). The underlying late Pleistocene glacial unit consists mainly of unfossiliferous, massive clay with occasional silt laminae, interbedded with thick sand or coarse silt turbidites (Nelson et al. 1995). The lower unit also contains diamicton beds of glaciallacustrine origin. This glacial-to-postglacial sequence is presumably repeated beneath the uppermost sediments, reflecting previous glacial-interglacial climate cycles, although these older cycles have not been documented by drill cores in the basins. Grain size and lithology vary in different subenvironments, and pelagic or hemipelagic sediments are intercalated with coarser deposits, but in general, all of the deposits beneath basin floors and marginal fans are dominated by turbidites during both glacial and interglacial intervals.

Reliable data on long-term sedimentation rates for these deposits are sparse, but sediment appears to accumulate on the basin floors faster than in any other sedimentary environment in the lake (Colman et al. 1996b). These high rates are caused by convergence of various components of the large turbidite systems in Lake Baikal on the basin floors. At core site 308 (Fig. 1) the average Holocene sedimentation rate is about $30 \mathrm{~cm} / \mathrm{kyr}(\mathrm{Col}-$ man et al. 1996b) and the late Pleistocene rate is probably higher. At site 323 in the North Basin, radiocarbon ages (Ogura et al. 1992) suggest that rates average $10-16 \mathrm{~cm} / \mathrm{kyr}$ in the Holocene and $33-73 \mathrm{~cm} / \mathrm{kyr}$ in the late glacial. Rates during full glacial intervals may be even higher, but no age information exists for full-glacial sediments in the turbidite basins. Other radiocarbon-based estimates of average sedimentation rates on the basin floor, for example, at site 295 (Bezrukova et al. 1991; Qiu et al. 1993) are probably not reliable (Carter and Colman 1994).

Small, sand-rich aprons tend to form along the base of the steep, borderfault slope on the northwestern side of the Lake Baikal basins. As with sandrich aprons in other settings (Nelson et al. 1986; Nelson et al. 1991), the base-of-slope aprons are characterized on seismic-reflection profiles by highamplitude, continuous to discontinuous, and wedging reflections that extend a few kilometers out from the base of slope (Fig. 3A). No channels are evident in the seismic profiles across aprons, and reflections gradually become flatter lying and more continuous downslope as the aprons grade into basin-plain deposits (Fig. 3B). In Lake Baikal, as in other examples (Nelson et al. 1986; Nelson et al. 1991; Nelson et al. 1995), high-amplitude seismic reflections and core lithology suggest that proximal sand-rich aprons are dominated by thick sand and gravel beds. The echo character of these sediments (strong, parallel, closely spaced reflections) and the sequence of sand beds in cores suggest that the apron-type deposits are longitudinally continuous. This pattern suggests that most of the sediment from flows feeding the aprons is deposited near the basin margins, although some fine-grained sediment may feed laterally onto the elongate basin plains (Fig. 3A).

Well-defined subaqueous fans 5-20 km in diameter (Fig. 4) occur along the sides of basin floors bordering the most extensively glaciated regions surrounding the lake and off local rivers such as the Frolikha and Tompuda (Figs. 1, 2) (Nelson et al. 1995; Back et al. 1998; Back et al. 1999). These sand-rich fans have distinct radial shapes and relatively steep slopes (Nelson et al. 1995); $3.5 \mathrm{kHz}$ profiles exhibit high surface reflectivity and little or no penetration, suggesting thick near-surface sand layers. This interpretation is confirmed by numerous sand beds in cores from the inner and middle parts of the slopes of these fans (Nelson et al. 1991; Nelson et al. 1995). Water-gun seismic profiles show strong, moderately continuous reflections beneath the fans, at slightly discordant angles to each other and to the fan surfaces (Fig. 4A), suggesting deposition in lobes. Near the distal margins of the fans, these reflections become horizontal and interfinger with the flat-lying reflections beneath the basin floors.

In orientations transverse to the fan axes, $3.5 \mathrm{kHz}$ profiles across the depositional lobes of sand-rich fans show, in addition to high reflectivity and little penetration, a convex-upward shape and numerous channels on the order of $100 \mathrm{~m}$ wide and $10 \mathrm{~m}$ deep (Nelson et al. 1995). The channels are also well defined on water-gun seismic profiles (Fig. 4A). In a distal direction, the fans exhibit lower reflectivity, deeper penetration, and more 


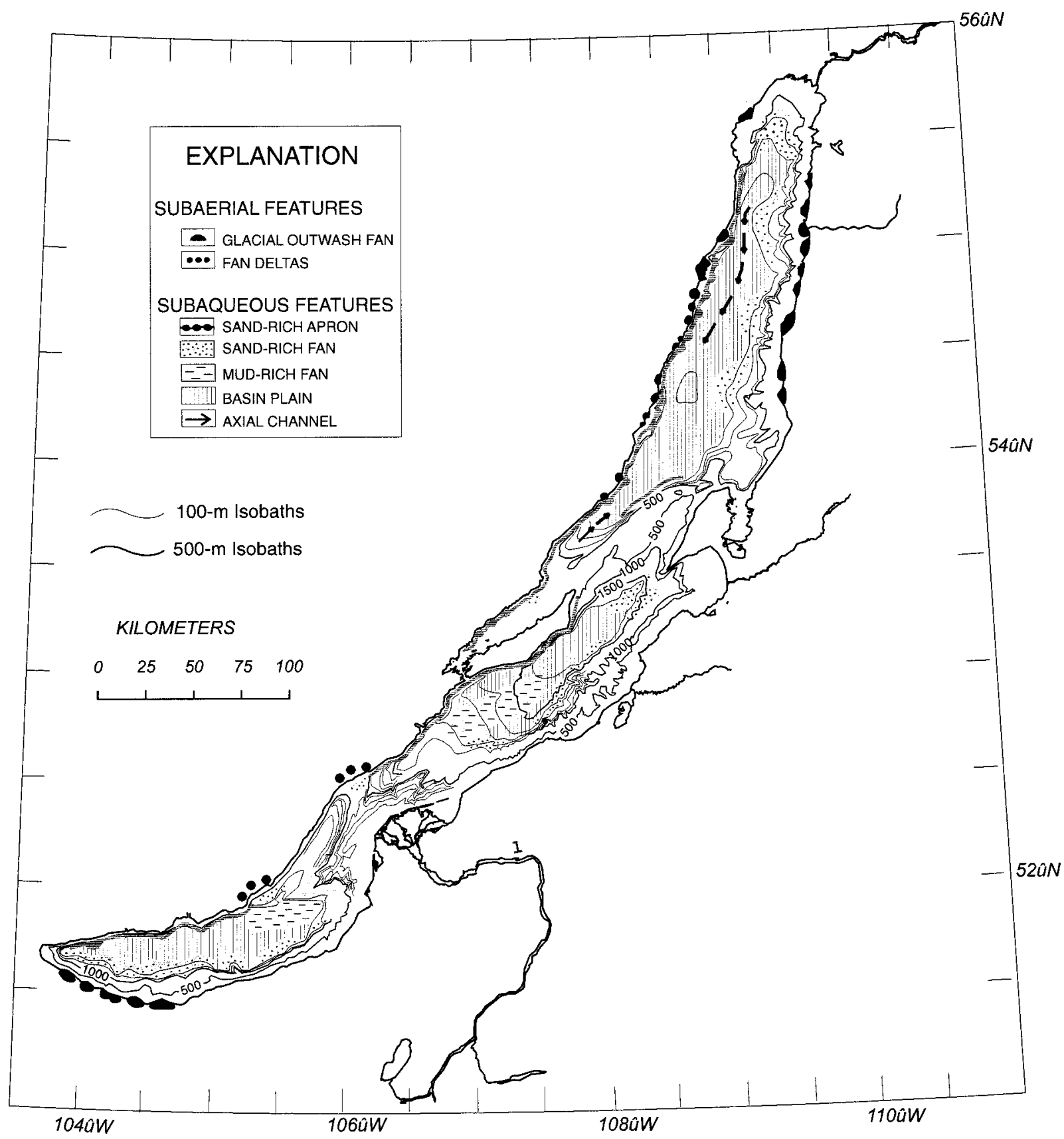

FIG. 2.-Generalized map of features related to turbidite systems in Lake Baikal, based on a variety of data and modified from Nelson et al. (1999). Locations of major banks and ridges (hemipelagic sedimentation) are shown in Figure 1, as are the rivers associated with major deltas.

continuity. Water-gun seismic profiles suggest that, on a larger scale, basinplain deposits laterally onlap and interfinger with lenticular, stacked lobes of these subaqueous fans (Fig. 4B).

On a much larger scale are the axial, low-gradient, subaqueous fans in Lake Baikal that emanate from the toes of large deltas. Many of these fans extend longitudinally down the axes of basins, fed by channels or canyons incised into the deltas. The most prominent of the delta-related fans are the two issuing from the toe of the Selenga Delta into the South and Central basins, respectively, and from the Upper Angara Delta into the north end of the North Basin (Back et al. 1999). The largest of these extends $65 \mathrm{~km}$ from the Selenga Delta to cover the southwestern half of the Central Basin. Our one longitudinal seismic profile of this morphologically distinct fan exhibits a high-reflectivity echo character, which suggests that sand is com- mon beneath the entire fan and adjacent basin plain (Nelson et al. 1995). Transverse profiles (e.g., Fig. 5) reveal numerous channels on the surface of the proximal part of this fan. Deeper penetration and better continuity of reflectors in areas outside channels and high-amplitude reflections beneath channel floors, as well as core lithologies, suggest a typical pattern of thin-bedded sands in overbank deposits adjacent to the channels and thicker sand beds beneath channel floors (Nelson et al. 1995). Many of the channel systems are associated with distinct channel-levee complexes that rise above the fan surface (Fig. 5).

The fans associated with the Selenga River source are classified as mudrich turbidite systems (Nelson et al. 1995; Nelson et al. 1999). The related turbidite beds are characterized by olive brown colors, higher silt contents, finer mean grain sizes, and lower sand contents than turbidites found in 

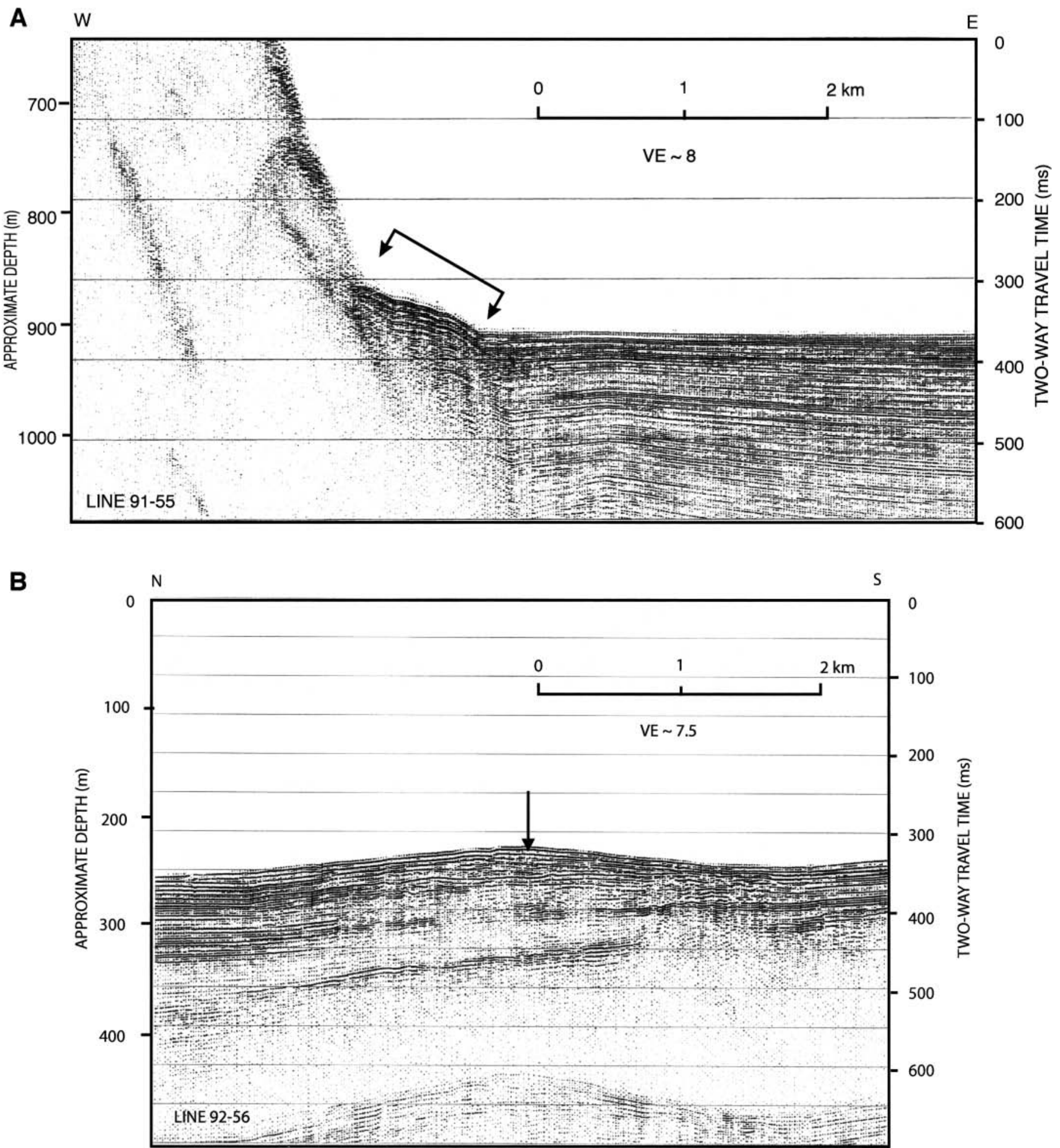

Fig. 3.-Water-gun seismic-reflection profiles showing base-of-slope aprons, identified in part by plan-view morphology. A) longitudinal section (line 91-55), apron indicated by arrows; B) distal cross section of apron with axis indicated by arrow (line 92-56). Locations shown in Figure 1.

sand-rich aprons and marginal fans of Lake Baikal. Selenga-derived silt turbidites nearly all contain less than 10 percent sand and exhibit mean grain size of 6-8 phi (0.0039-0.0156 mm) diameter, compared to sandy turbidites from sand-rich aprons and fans, which nearly all contain greater than 20 percent sand and exhibit mean grain sizes of $2-6$ phi $(0.0156-0.25$ $\mathrm{mm}$ ) diameter. Compared to the sand-rich aprons and fans, the mud-rich fans emanating from the Selenga Delta are larger, of lower gradient, and have more extensive channel systems.

Turbidite deposits are ponded in the central part of the basin plains in all Lake Baikal basins (Fig. 6). The laterally fed, sand-rich aprons and fans, 

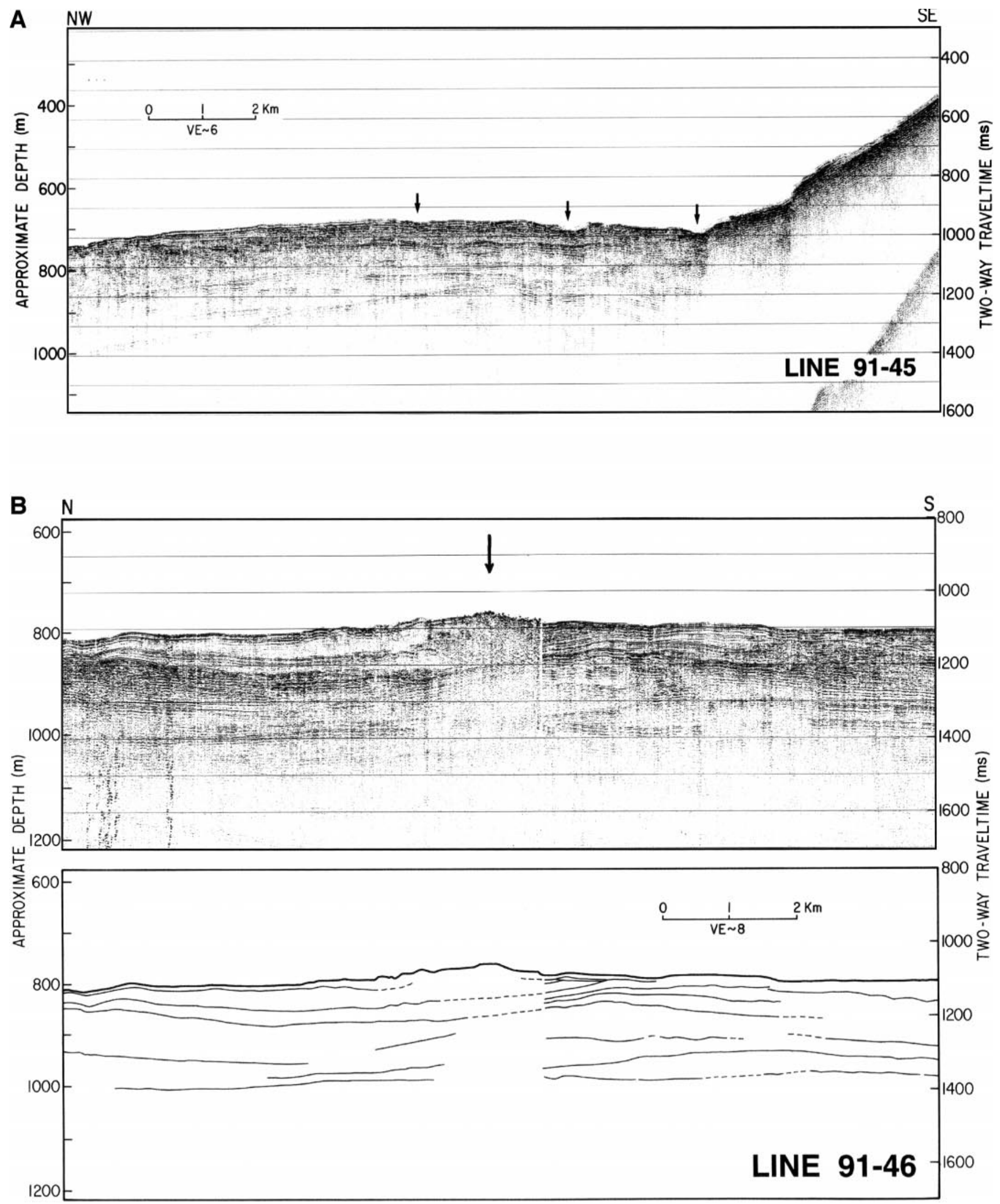

FIg. 4.-Water-gun seismic-reflection profiles showing medium-size, sand-rich, channeled fans. A) Oblique section (line 91-45), channels indicated by arrows; B) distal cross section (line 91-46), showing stacked fan lobes; arrow indicates present fan axis; examples of lobe margins occur just south of the axis. Locations shown in Figure 1. 


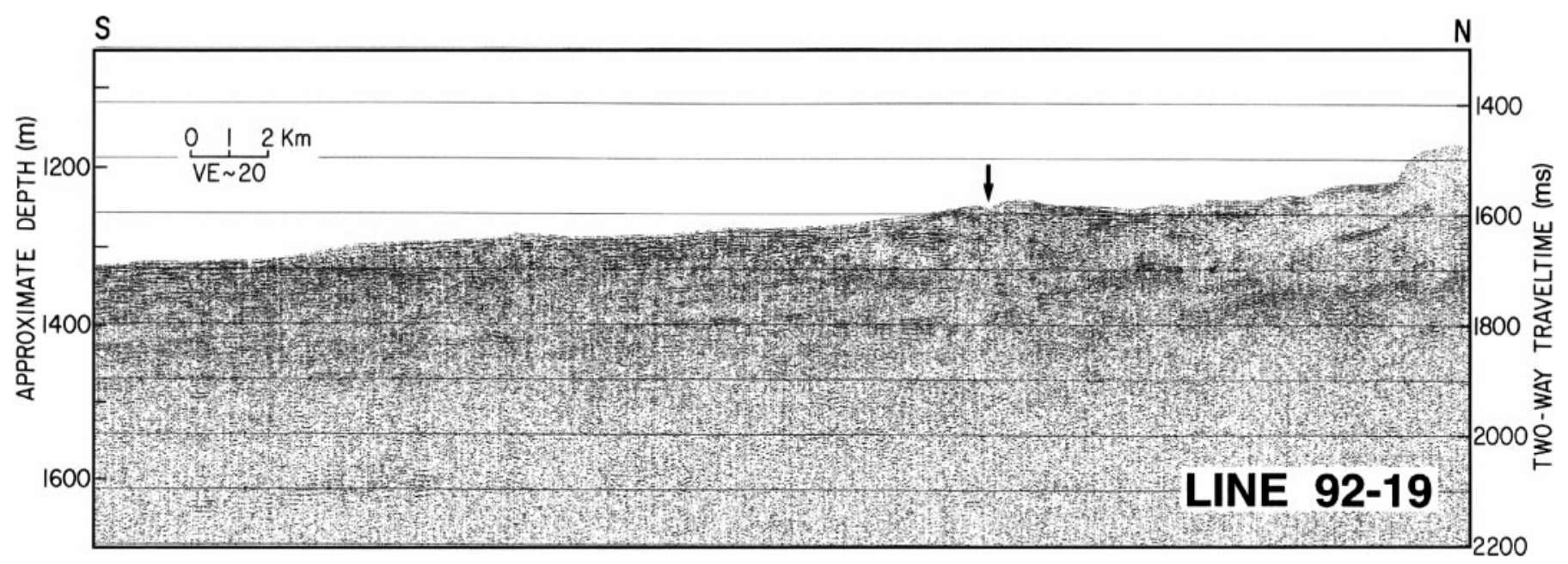

FIG. 5.-Water-gun seismic-reflection profile (lines $92-18$ and -19) oblique to Selenga fan leading into the Central Basin. Note prominent channel and associated levee complex indicated by arrow. Location shown in Figure 1.

as well as the large, longitudinally fed, mud-rich fans, all feed these ponded basin-plain turbidite deposits (Nelson et al. 1999). In high-resolution seismic profiles, the basin-plain facies is characterized by good acoustic penetration and reflection continuity (Fig. 6). The basin-plain facies onlaps, interfingers with, and grades into the facies deposited in aprons, lateral fan lobes, and longitudinal mud-rich fans. Axial channels of the subaqueous fans sometimes extend onto the basin plains, and commonly their position is controlled by rift-parallel faults that offset the basin-plain deposits. The overall geometry of these systems, including lobate fans, multiple channels, and gradation or interfingering with ponded turbidite deposits suggests temporally and spatially discontinuous depositional events. These events are integrated and stacked over time to form the observed morphology and stratigraphy.

\section{Selenga Delta}

The Selenga delta forms the single most conspicuous depositional feature in Lake Baikal, burying the southeast margin of the rift and prograding more than halfway across the lake. Although the delta separates the deep South and Central basins, the relief between the basins and the delta is not entirely the result of deposition. The delta has been constructed atop a complex accommodation zone of basement blocks that have subsided along both the main faults of the northwest rift margin and transverse faults (Hutchinson et al. 1992; Scholz and Hutchinson 2000). A major fault is present beneath the delta front, where basement is offset from a depth of $3.6 \mathrm{~s}$ (two-way travel time) on the southwest to more than $7.0 \mathrm{~s}$ on the northeast (Hutchinson et al. 1992; Scholz and Hutchinson 2000). Posolsky Bank on the southern side of the delta is a massive tilted fault block. The southwestern side of the delta covers a small half-graben subbasin, the Selenga basin, containing about $9 \mathrm{~km}$ of sediment (Scholz and Hutchinson 2000). Thus, the overall morphology of the delta has formed as a result of a complex combination of depositional and tectonic processes.

The general morphology of the Selenga Delta is a classic one. Its delta plain, just above lake level, protrudes in a half-circle into the lake along an otherwise linear rift-margin shoreline (Figs. 1,2). The delta front slopes towards the opposite side of the lake and toward the flanking South and Central basins at relatively steep (3 to 5 degrees) angles. The delta toe is formed by the Buguldeika saddle on the north and by the large, subaqueous fans to the northeast and southwest, which form the transition from the delta to the basin floors. The Selenga River carries more than half of the total water discharge into the lake (Kozhov 1963); total sediment discharge is unknown but is likely equally significant. In addition to its massive delta, the Selenga feeds the huge subaqueous fans that emanate from the toe of the delta and extend into the South and Central basins. Much of the sediment that is eventually deposited in these two basins originates from the Selenga River and its delta.

Evidence for large-scale and rapid subsidence beneath the delta is abundant. Subsidence locally has been great enough that some synrift sedimentary units thicken toward the center of the Selenga Basin, away from the main border fault (Scholz and Hutchinson 2000). In the younger part of the section, rapid rift subsidence has caused several sets of prograding seismic units to be buried beneath a mantle of about 100 meters of uniformly bedded, more recent sediment (Fig. 7). The prograding sequences, also seen in multichannel seismic data (Scholz et al. 1998; Scholz and Hutchinson 2000), consist of multiple sets of small-scale, sigmoidal reflections typical of sediments deposited in shallow-water, prograding, deltaic environments. The prograding deltaic sequences, presumably deposited in shallow water, now occur at depths of 100-400 m. Similar sequences may be forming today at the edge of the delta plain, in water shallower than that from which our profiles were obtained.

The change from the shallow-water, prograding units to the overlying deep-water, draped unit indicates a rapid and relatively recent acceleration of subsidence in the delta area. Other explanations for this change, such as switching among depositional lobes of the delta, are less plausible, because the hemipelagic draped unit maintains a relatively uniform thickness across much of the front of the delta (Fig. 8).

Further evidence of active recent subsidence is provided by a series of graben-like structures on the upper delta front that parallel the curvilinear break in slope at the distal edge of the delta plain (profile, Fig. 7; map view, Fig. 8). The graben structures indicate tensional stress, and the curved pattern and its relation to the break in slope of the delta suggests an association with deltaic deposition. We infer that this graben-like feature is the result of flexure of the sediments as they subside into the basin in which they are being deposited. This relation suggests that active subsidence is currently accompanying deposition of the delta.

Recent displacements on splays of basement faults, many of which offset the lake floor, have had profound effects on sediment distribution on the Selenga Delta. Because the delta front extends almost to the opposite (northwest) side of the rift, and because the accommodation zone beneath the delta contains a complex of oblique faults (Fig. 8), many modern fault scarps face up the depositional slope of the delta (Fig. 9). Most major channels and canyons on the delta are controlled by fault scarps; in particular, channels oriented subparallel to the rift are controlled by upslope- 

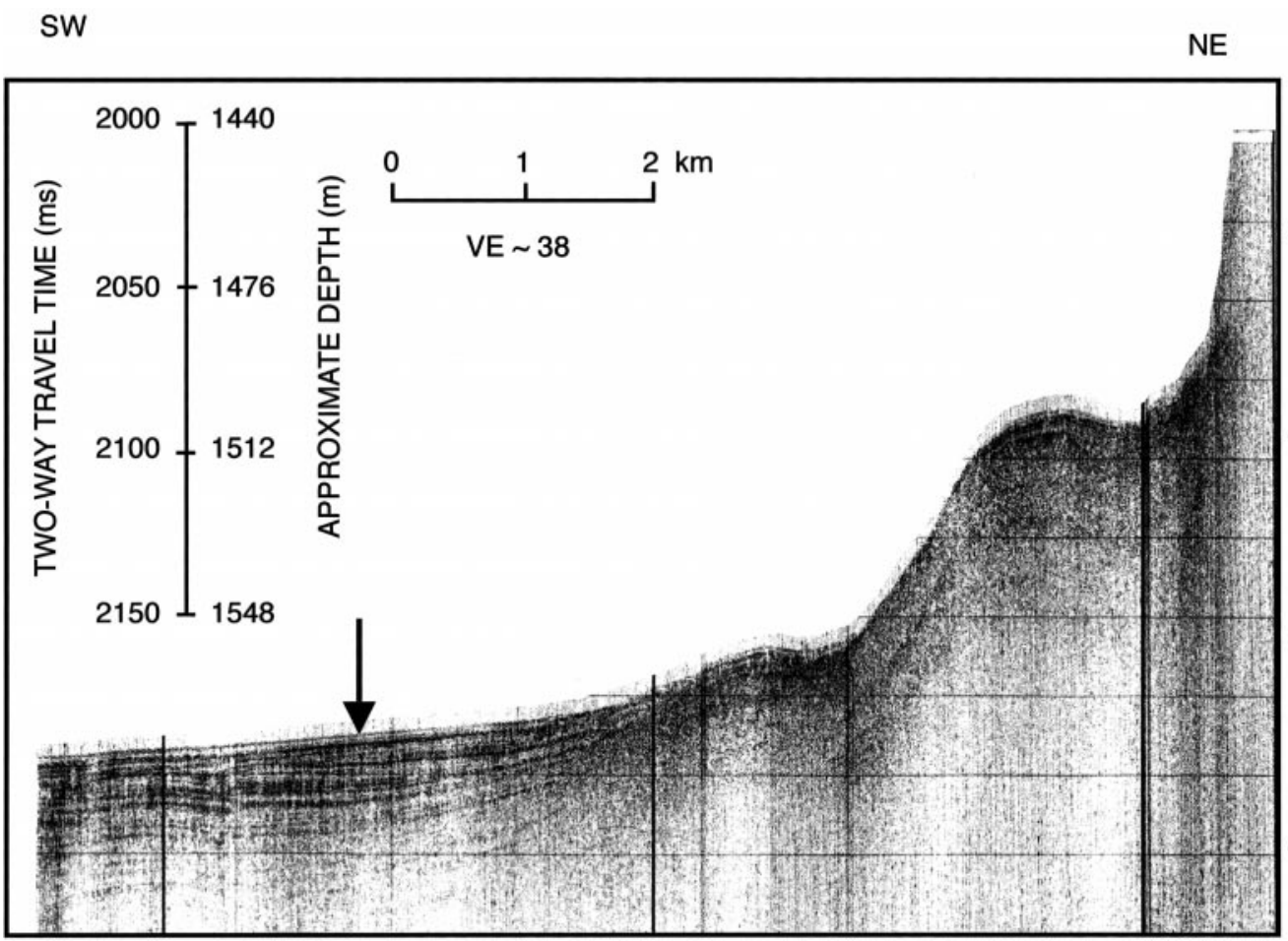

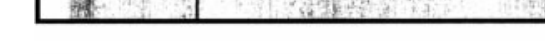

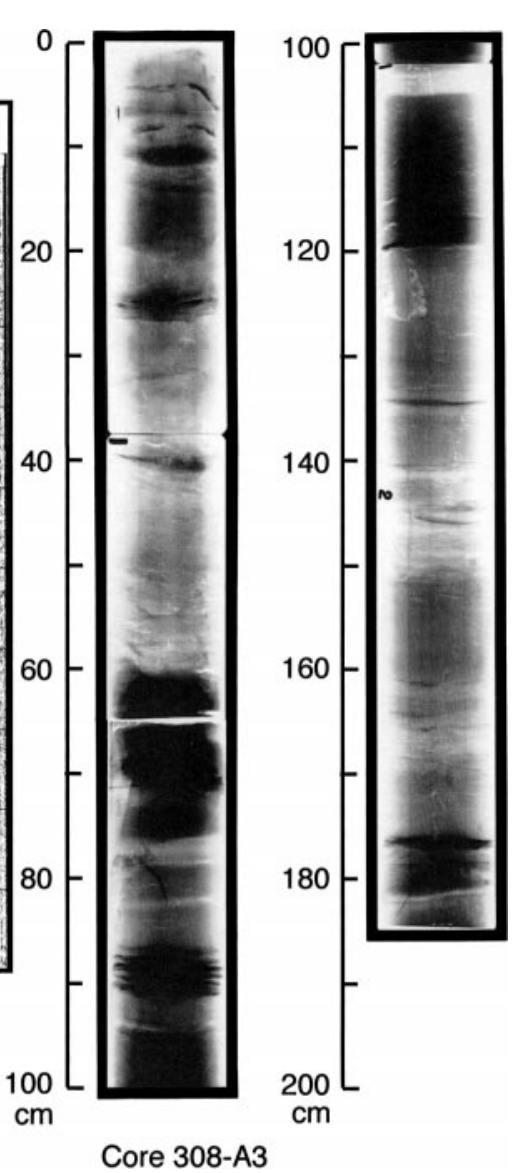

Core 308-A3

FIG. 6.-Seismic-reflection profile (line 90-1; $3.5 \mathrm{kHz}$ ) through core site 308, on the floor of the Central Basin near its margin. Inset, X-radiograph of core 308-A5 showing coarse turbidites (dark) interbedded with distal, fine-grained turbidites and hemipelagic sediments. Location shown in Figure 1.

facing fault scarps. These channels divert most coarse-grained sediment to the sides of the delta, away from the modern delta front. The channels feed the large, longitudinal, subaqueous fans that grade to the turbidite-dominated floors of the South and Central basins.

The channel and canyon systems that feed the subaqueous fans divert much of the sediment contributed by the Selenga River away from the surface of the delta front. As a result, any actively prograding depositional lobes are restricted to relatively shallow water (shallower than our seismic profiles) and are absent from much of the delta front. Instead, the delta front is mantled by about $100 \pm 20 \mathrm{~m}$ of evenly bedded silt and clay (Figs. 7, 9). This uppermost unit on the delta front shows no cut-and-fill structures, no lensing or rapid changes in thickness, no channel-levee features, and only local evidence of mass movement. The sediments appear to be mostly hemipelagic mud (Colman et al. 1994b) derived primarily from suspended sediment of the Selenga River, but which also contain biogenic silica in amounts ranging from near zero during glacial periods to 20-35 percent during interglacial intervals (Carter and Colman 1994). Widespread suspended sediment from distant turbidity currents may also contribute to these deposits.

Sedimentation rates at three sites on the delta for about the last hundred years are approximately $0.1 \mathrm{~cm} / \mathrm{yr}(100 \mathrm{~cm} / \mathrm{kyr})$ based on ${ }^{210} \mathrm{~Pb}$ analyses (Edgington et al. 1991). For the last 30,000 years, well documented by radiocarbon ages (Colman et al. 1996b), sedimentation rates are between 15 and $19 \mathrm{~cm} / \mathrm{kyr}$ at all sites (four) except for one (316) located on the crest of a fault scarp. These sedimentation rates are lower than those estimated from ${ }^{210} \mathrm{~Pb}$ methods because the latter are for the uppermost $35 \mathrm{~cm}$ of sediment, which is water-rich and uncompacted. The relatively small variation in ${ }^{14} \mathrm{C}$-derived sedimentation rates among sites is consistent with the continuous, evenly bedded character of the sediments and with a mostly hemipelagic origin.

\section{Academician Ridge}

Academician Ridge is a bathymetric and structural high, an "accommodation zone" (Hutchinson et al. 1992; Scholz and Hutchinson 2000) between the North and Central basins. Compared with the Selenga Delta accommodation zone, it is relatively simple, bounded by segmented, largedisplacement, high-relief normal faults. The Academician Fault, a major active oblique-slip fault (Mats et al. 2000), is also present along the crest of the ridge. Many of these faults have complex histories and senses of movement because of reactivation, changes in position with respect to the rift margin, and southward propagation of the North Basin rift (Hutchinson et al. 1992; Agar and Klitgord 1995; Moore et al. 1997; Mats et al. 2000).

Because of its position and depth, Academician Ridge receives only a slow rain of hemipelagic sediment. It is isolated from the direct influence of rivers or turbidity currents. The southwestern part of the ridge has clearly experienced episodic erosion and (or) redeposition of its hemipelagic sediment. This part of the ridge consists of isolated knobs and sub-ridges, which are covered by variable thicknesses of sediment, some of which is ponded and (or) otherwise redistributed (Fig. 10). Other seismic-reflection data (Ceramicola et al. 2001) have documented small sediment mounds and intervening moats on the southwestern part of the ridge, as well as localized lacustrine drift deposits on part of the central section of the ridge. All of these data suggest active sediment reworking and erosion by bottom currents. Deep-water mixing processes in the Central and North basins of Lake Baikal appear to require flows across Academician Ridge (Hohmann 


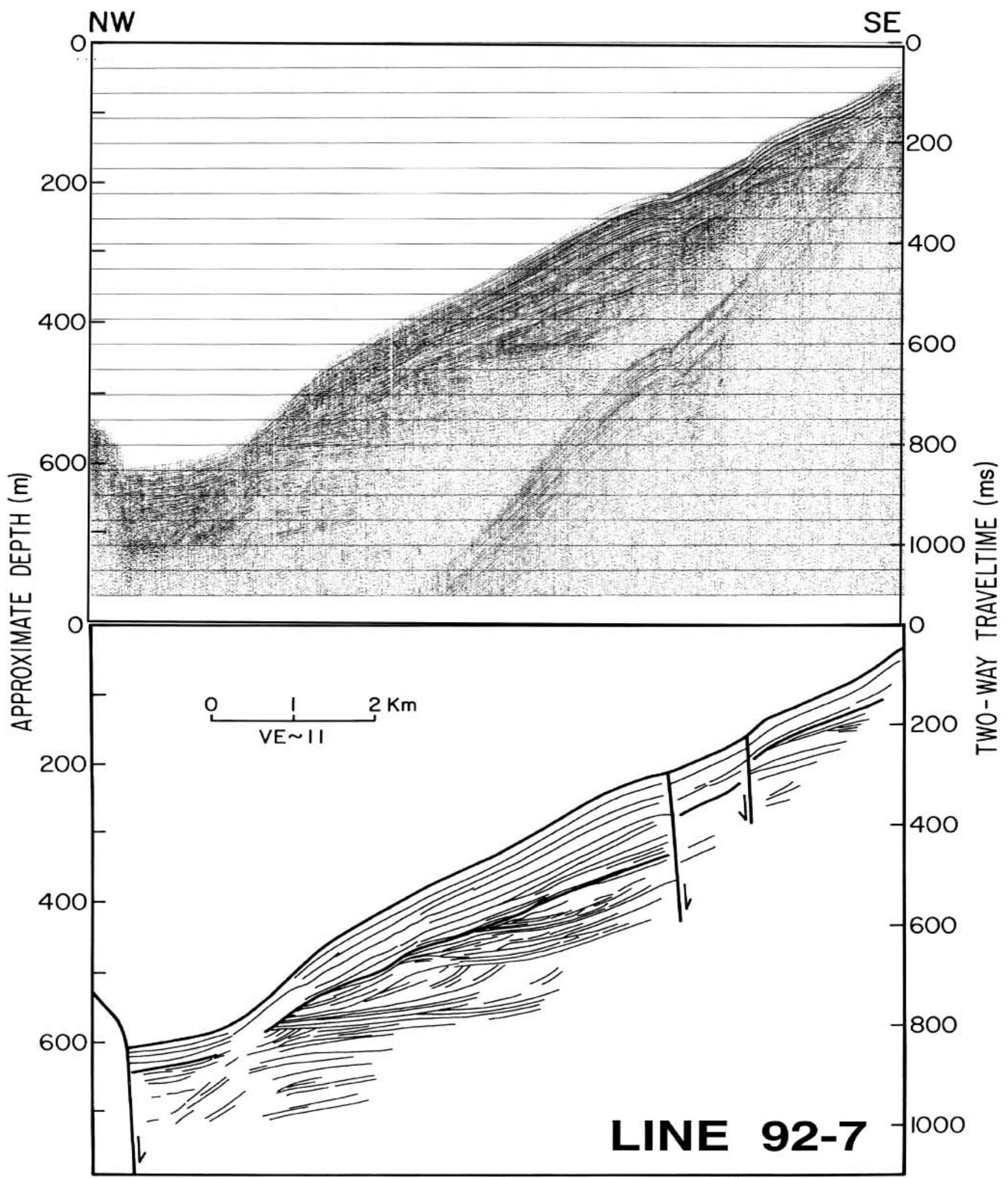

FIG. 7.-Water-gun seismic-reflection profile (line 92-7) across the front of the Selenga Delta, showing multiple packages of prograding units with well-defined sigmoidal internal reflections, overlain by draped, evenly bedded unit. Location shown in Figure 1. 


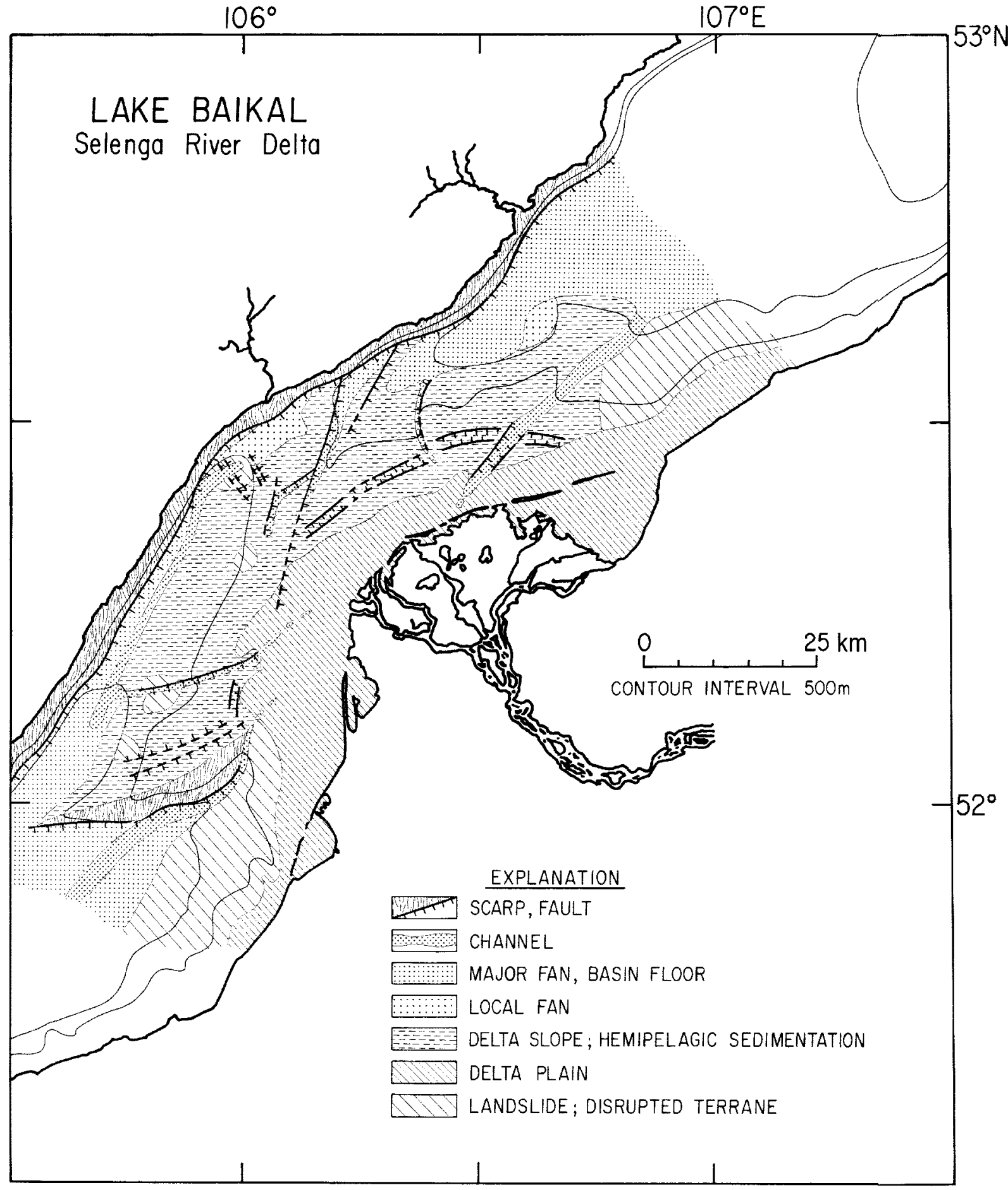

FIG. 8.-Map showing depositional environments, morphological features, and fault scarps in the Selenga Delta area.

et al. 1997), and the small-scale sediment features suggest bottom water flows to the north-northeast (Ceramicola et al. 2001).

A core (341) taken on one of the knobs where the seismic data showed no penetration recovered coarse gravels that formed two cycles of finingupward, presumably shallow-water sequences. These gravels are likely quite old, given the arguments (Colman 1998) against significant climatically controlled changes in lake level for much of the Quaternary. They may be equivalent to shoreline gravels of the Sasa Sequence on land, assigned a late Miocene-early Pliocene age (Mats et al. 2000).
On the northeastern part of the ridge, however, seismic profiles indicate mostly continuous, parallel-bedded sedimentary layers, consistent with a hemipelagic origin, especially on the southeast side of the Academician Fault (Fig. 11). Continuous, slow sedimentation on this part of the ridge has been confirmed by piston cores (Peck et al. 1994; Colman et al. 1995; Edgington et al. 1996) and drill cores (BDP Members 1997b; Williams et al. 1997; Kuzmin et al. 2000). These sediments consist of alternating diatomaceous muds and barren glacial clays, corresponding to interglacial and glacial periods, respectively (Granina et al. 1993; Colman et al. 1995; Wil- 


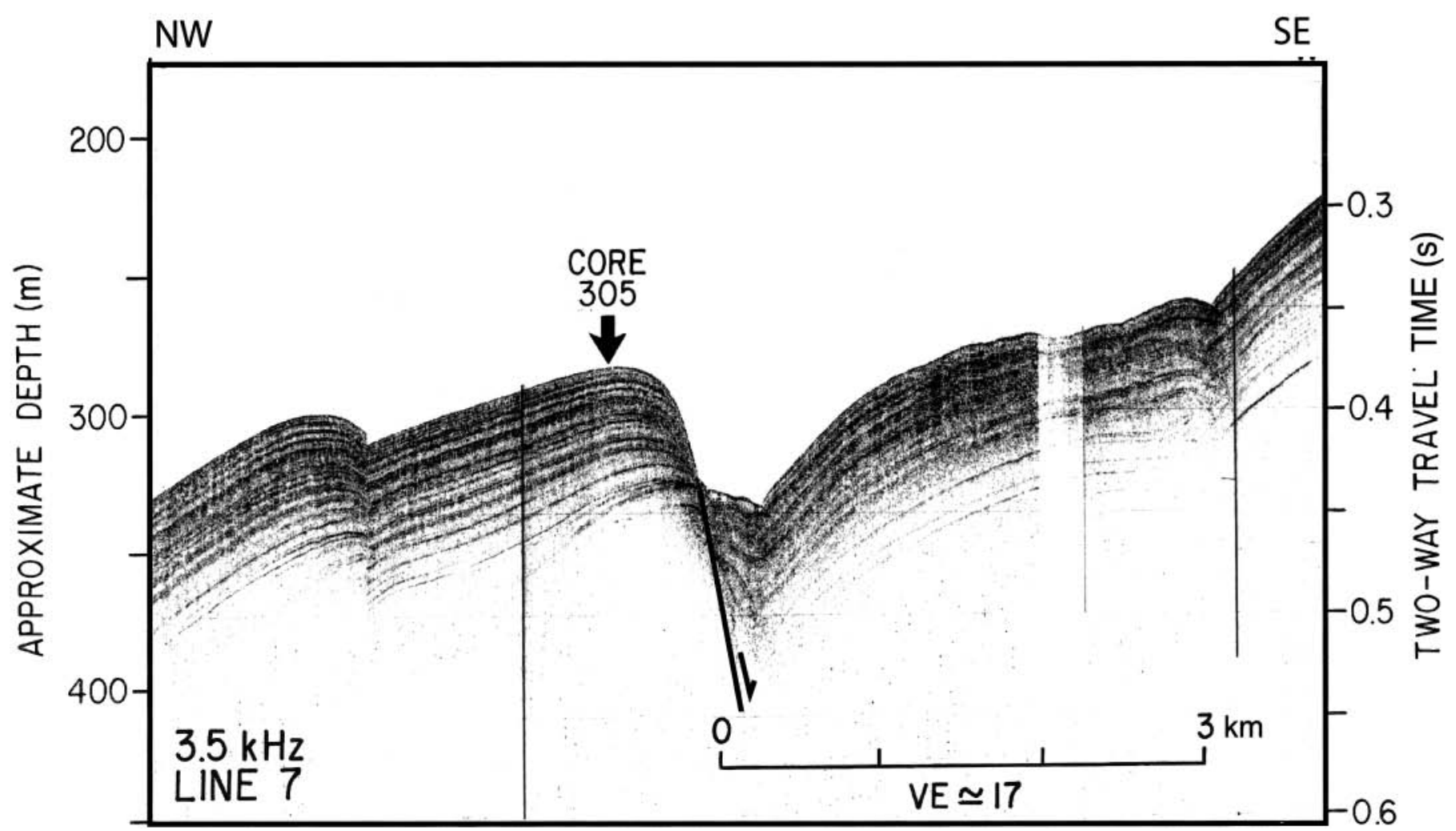

FIG. 9-Seismic-reflection profile (line 90-7; $3.5 \mathrm{kHz}$ ) through core site 305, on the lower slope of the Selenga Delta, showing upslope-facing fault scarps and the continuous, evenly bedded character of the upper draped unit. Location shown in Figure 1.

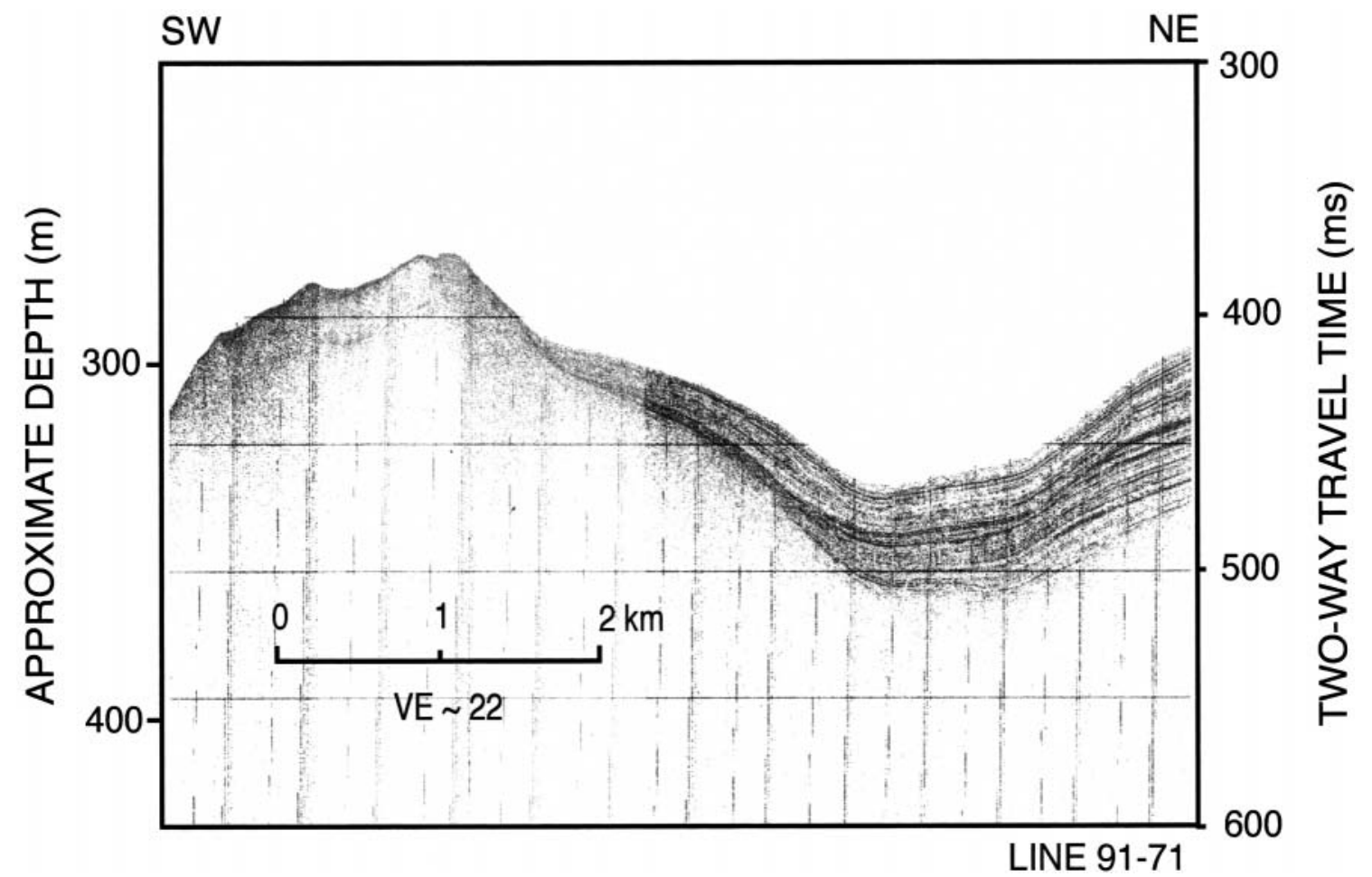

FIG. 10.-Seismic-reflection profile (line 91-71; $3.5 \mathrm{kHz}$ ) on the southern part of Academician Ridge, showing depositional thickening and thinning of units, as well as erosion. Location shown in Figure 1. 


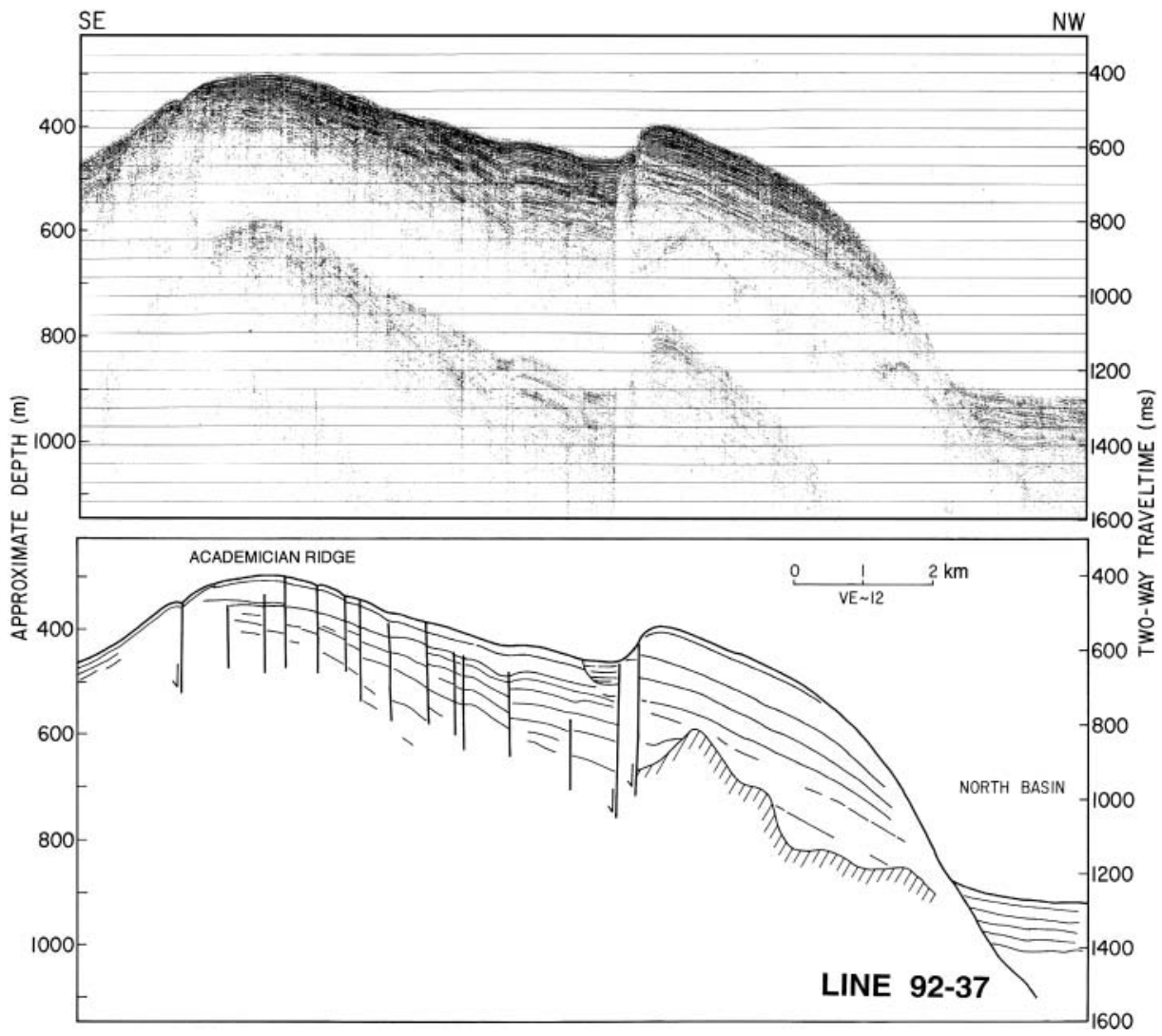

FIg. 11.-Water-gun seismic-reflection profile (line 92-35) on Academician Ridge, The continuously bedded upper sequence is cut by the oblique-slip Academician Fault, underlying the ridge-parallel trough near the center of the profile. Location shown in Figure 1. liams et al. 1997). Biogenic silica contents range from near zero in glacial sediments to 50 percent by weight in interglacial deposits. As the ridge gradually becomes broader to the northeast, strike-parallel seismic profiles show that the upper section of sediments becomes continuous and evenly bedded (Fig. 12), disturbed only by several closely spaced, small-verticaldisplacement fault splays along the crest of the ridge.

Radiocarbon ages indicate very slow sedimentation rates during the last 13,000 years, approximately 3-5 cm/kyr (Colman et al. 1996b). At site 340, correlation of magnetic properties (Peck et al. 1994) and biogenic silica profiles (Colman et al. 1995) with the marine oxygen isotope record suggests a remarkably uniform sedimentation rate of about $4.0 \mathrm{~cm} / \mathrm{kyr}$ for the last 250,000 years, at least when averaged over climate cycles. Similar correlation of uranium-series contents at a nearby site with the oxygen isotope record indicate an equally uniform sedimentation rate of about 3.7 $\mathrm{cm} / \mathrm{kyr}$ for the same time frame (Edgington et al. 1996). Lithologic and paleomagnetic data from the BDP96 drill hole near site 340 suggest that the uniformity in lithology and sedimentation rates on Academician Ridge persist not only to the Brunhes-Matuyama paleomagnetic boundary (780 ka; Baksi et al. 1992) but also to the base of the core at about $5 \mathrm{Ma}$ (Williams et al. 1997).

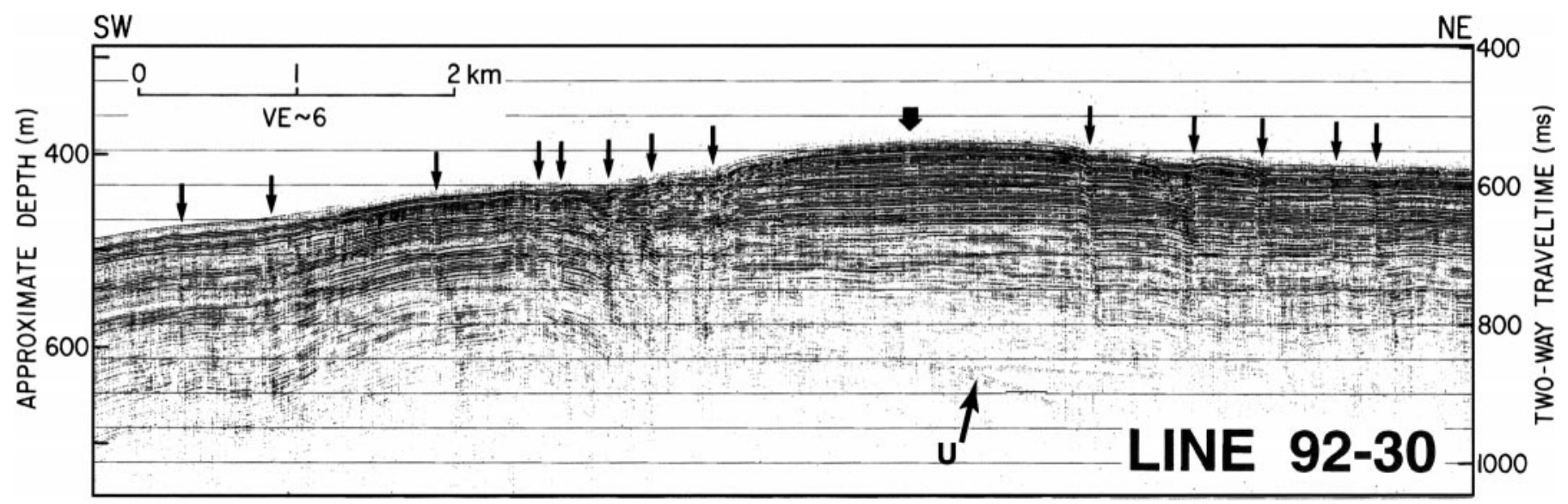

FIG. 12.-Water-gun seismic-reflection profile (line 92-30) along Academician Ridge, showing continuous, evenly bedded sediment sequences. Small arrows show location of oblique-slip faults; large arrow shows the planned location for BDP96; actual location was about $2 \mathrm{~km}$ south. "U" indicates angular unconformity discussed in text. Location shown in Figure 1. 


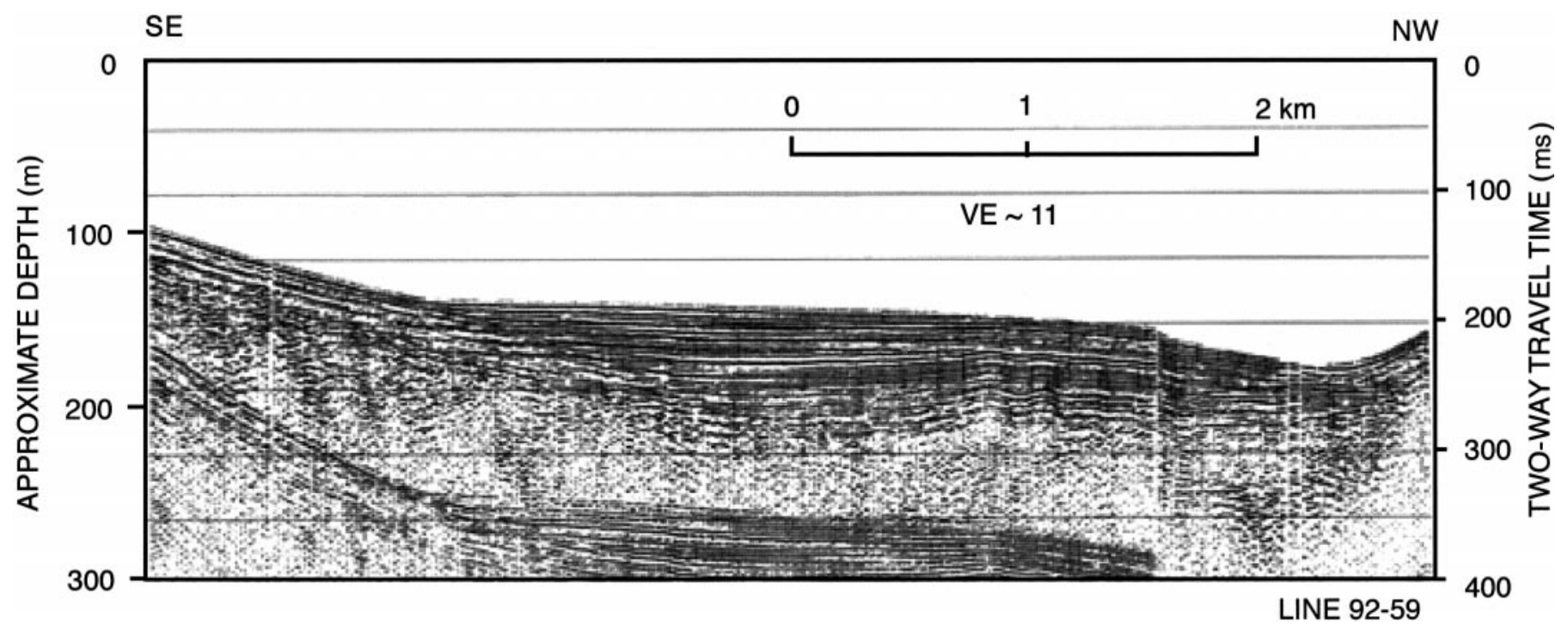

FIg. 13.-Water-gun seismic-reflection profile (line 92-59) in Maloe More, showing floor of rift basin tilted toward the Primorsky Fault (to right of profile). Location shown in Figure 1.

\section{Other Environments}

Other less extensive sedimentary environments exist in Lake Baikal. Steep canyons cut many of the rift margins and are of both biological and sedimentological interest (Karabanov and Fialkov 1987). The southeast slopes of the Central and South basins have received relatively little investigation, but they seem to be characterized by widespread mass-movement features. This mass movement may have caused small-amplitude folding in sediments beneath the floor of the South Basin (Taliev and Bardardinov 1993)

The sediments in Maloe More (Small Sea) (Fig. 1), a young extension of the North Basin rift between Olk'hon Island and the mainland (Agar and Klitgord 1995), are particularly intriguing. Large fan deltas have formed at the mouths of several of the streams that flow into this basin. Despite the steep terrain and large fans, only small, unchanneled aprons have formed at the base of the subaqueous slope (Fig. 13A). In addition, the geometry of sediment accumulation on the floor of the Maloe More basin suggests rapid tectonic tilting. The situation is complicated by bottom currents, which have created a density-flow channel that partially erodes sediments on the basin floor (the depression on the right side of Fig. 13). Nevertheless, to the southeast of this channel, sediments accumulating on the basin floor and lapping onto older units slope toward the border fault (the Primorsky Fault) on the northwest, rather than being flat (Fig. 13). These observations suggest that movement on the Primorsky Fault is so rapid that sediment accumulations below the fan deltas are buried before they can form large subaqueous fans, and that the tectonic tilting of the basin floor occurs faster than it can be leveled by deposition.

The sediments in Maloe More contain the highest diatom concentrations of any location yet documented in Lake Baikal. During interglacial periods, including the present, the sediment composition approaches diatomite, with biogenic silica contents of more than 80 percent (Carter and Colman 1994). Both biogenic silica and pollen (Y. Bezrukova, written communication, 1994) are better preserved in cores from site 342, at the mouth of Maloe More, than they are in cores from other sites, although the content of both diatoms and pollen is low during full glacial periods. The sedimentation rates at site 342 for the postglacial period is about $11 \mathrm{~cm} / \mathrm{kyr}$ (Colman et al. 1996b). The reason for the high degree of preservation of both diatoms and pollen in the sediments of Maloe More has not been investigated, but this preservation makes the sediments there attractive for paleolimnological analysis.

\section{DISCUSSION}

\section{Lake Level, Tectonics, and Turbidites}

Lake level, or perhaps better, water depth, is clearly an important component of reconstructed lacustrine depositional environments. In modeling the sedimentation represented by profile $92-9$, similar to and just east of the one in Figure 7, Romashkin et al. (1997) estimated that lake level had varied by as much as $300 \mathrm{~m}$ below to $200 \mathrm{~m}$ above present lake level during the last 600,000 years. They ascribed these changes in apparent water depths to a combination of tectonic submergence and climatically induced changes in water depth. However, climatic control of the level or depth of Lake Baikal during the past several hundred thousand years is probably negligible (Colman 1998). The hydrologic balance and the outlet configuration of the lake make it difficult to change lake level climatically. Evaporation is less than one-sixth of the outflow (Kozhov 1963), and the mean residence time of water in the lake is only 300-400 years (Weiss et al. 1991; Faulkner et al. 1991). No evidence exists for anything other than a dilute, through-flowing lake controlled by the level of its outlet, which could easily accommodate higher outflow without significant changes in lake level, during the last several hundred thousand years. Even if climatic changes affected lake level, such changes would be difficult or impossible to separate from lake-level changes caused by tectonism (Colman 1998). Tectonism clearly affects the relative water level of Lake Baikal, by controlling the level of the outlet. Tectonism also may cause geologically abrupt changes in the location of the outlet, which last occurred at perhaps 0.8 Ma (Mats 1993). Overall, though, the situation in Lake Baikal contrasts markedly with that of lakes in large basins that are at least episodically closed (e.g., Scholz et al. 1998), where chronologic data and seismic stratigraphy show clear evidence for climatically induced lake-level changes.

Tectonism affects virtually all aspects of sedimentation in Lake Baikal. Subsidence of the rift and uplift of the rift shoulders provide both the accommodation space for sediment deposition and the high subaerial and subaqueous relief that characterize the basin. In general, the Baikal basin is a high-relief and high-energy environment with intimate relationships between tectonism and sediment deposition. These relationships include growth faults on the basin floors, control of canyon and channel location, ponding of sediment against fault scarps, flexural tension on the upper slope of the Selenga Delta, rapid changes from shallow-water to deep-water facies, and differential ages of sediment sub-basins. 
In the high-energy environment of Lake Baikal, turbidite systems dominate a high percentage of the basin area. The steep basin margins, the broad subaqueous fans, and the flat basin floors are all shaped by turbiditycurrent processes. Deep-water fans are associated with virtually all streams entering the lake, ranging from the small, unchanneled base-of-slope aprons off small streams, to larger channeled fans off intermediate streams, to the huge subaqueous fans that lead from the toes of large deltas, such as the Selenga, to the basin-plain floors.

The relative importance of different sources of sediment for the turbiditycurrent systems are not entirely clear. Direct sediment input from rivers is certainly important, as is failure of previously deposited sediments on slopes. On the Selenga Delta, sediment from both of these sources appears to be largely directed through fault-controlled channels and canyons. This does not appear to be true of other large deltas, such as that of the upper Angara (Back et al. 1999). In general, the episodic nature of the coarser sand and silt beds suggests that commonly they result from sediment failure associated with oversteepening of slopes or seismic shaking.

\section{Accumulation Rates and Age Calculations}

Sediment-accumulation rates vary by more than an order of magnitude in Lake Baikal, the fastest being on the basin floors $(>30 \mathrm{~cm} / \mathrm{kyr})$ and the slowest being on ridges or banks (ca. 3-4 cm/kyr). Sediment-accumulation rates on the lower Selenga Delta are about $15-20 \mathrm{~cm} / \mathrm{kyr}$. At most sites, rates have been approximately constant for the past 13,000 years. Sedimentation on the basin floors during the last glaciation (ca. 15-25 ka) seems to have been significantly faster than that during the Holocene. The combination of biogenic sedimentation, which is greater during interglacial intervals, and terrigenous sedimentation, which is greater during glacial intervals, tends to subdue changes in overall sedimentation rate due to climate, but the relative balance between the two depends on local factors.

Cyclic Quaternary climate changes may be the most important control on turbidite sedimentation rates on time scales of $10^{4}$ years. In the turbidite systems of most marine and large-lake environments, climatic control on turbidite activity has been ascribed to water-level changes (Nelson et al. 1999). Except for relatively gradual tectonic effects, lake level in Baikal has been stable for the last several hundred thousand years (Colman 1998), so climatic effects on turbidite systems in Lake Baikal must be largely through changes in sediment supply (Nelson et al. 1998). Seismic studies of deposits related to glaciated drainages in the North Basin suggest that much of the basin fill is related to glacial outwash, and that large fans that were active during glacial times are largely inactive today because of a lack of course sediment supply (Back et al. 1999). Thus, turbidite sedimentation was likely more rapid during glacial episodes (Nelson et al. 1999).

Most of the drilling and coring in Lake Baikal has been aimed at recovering paleoclimate records, for which fine-grained sediments and the absence of turbidites are desirable. Consequently, long-term rates of sediment accumulation measured so far may be biased toward low values. No long, continuous cores have yet been obtained from the basin floors, so no direct estimates of turbidite accumulation rates through full climatic cycles are available. The available estimates (Ogura et al. 1992; Colman et al. 1996b) may not capture the maximum full-glacial rates. Lithologic data, as well as the ages from site 323 , suggest that turbidite sedimentation rates during glacial periods were somewhat higher than those during interglacial periods (Nelson et al. 1999). The lack of age estimates for full-glacial turbidite sedimentation may also explain why long-term rates of sediment accumulation measured so far in Lake Baikal are somewhat less than those measured in other large rift lakes, which are typically closer to $100 \mathrm{~cm} /$ kyr (Cohen et al. 1993; Scholz and Hutchinson 2000).

Accumulation of sediments in rift basins can be used to estimate the age of the basins, and thus the age of initiation of rifting (Cohen et al. 1993; Lezzar et al. 1996). Although subaerial stratigraphy and structure some-
TABLE 1.-Ages derived by the reflection-seismic radiocarbon method (RSRM; Cohen et al. 1993) for selected horizons in Lake Baikal.

\begin{tabular}{|c|c|c|c|c|}
\hline Datum & $\begin{array}{l}\text { Depth to } \\
\text { Base }(\mathrm{m})^{1}\end{array}$ & $\begin{array}{c}\text { Un- } \\
\text { compacted } \\
\text { Thickness } \\
(\mathrm{m})^{2}\end{array}$ & $\begin{array}{c}{ }^{14} \mathrm{C} \\
\text { Sedi- } \\
\text { mentation } \\
\text { Rate }(\mathrm{cm} / \\
\mathrm{kyr})^{3}\end{array}$ & Age (Ma) \\
\hline Base of Central Basin section & 7,500 & 12,285 & 50 & $24.6^{4}$ \\
\hline Base of North Basin Section (south part) & 3,500 & 5,636 & 50 & $11.3^{4}$ \\
\hline Depth to B10 horizon of Moore et al. (1997) in North Basin & 1,280 & 1,947 & 50 & 3.9 \\
\hline 10-m depth on Academician Ridge & 10 & 10.1 & 4 & 0.25 \\
\hline 200-m depth on Academician Ridge (BDP96) & 200 & 238 & 4 & 5.9 \\
\hline Unconformity at $230 \mathrm{~m}$ on Academician Ridge & 230 & 279 & 4 & 6.9 \\
\hline 100-m depth on Buguldeika Saddle (BDP93) & 100 & 111 & 19 & 0.58 \\
\hline Base of draped unit, Selenga Delta & 100 & 111 & 17 & 0.65 \\
\hline
\end{tabular}

${ }^{1}$ Base of Central and North Basin sections from Hutchinson et al. (1992); base of draped unit from this paper.

${ }^{2}$ Calculated from exponential decrease in porosity (Sclater and Christie 1980): $P=P_{0} e^{-b z}$, where $P=$ porosity, $P_{0}=$ original porosity, $b$ is a constant, and $z$ is depth. This expression was fit to data from BDP93 (BDP Members 1997a), yielding $P_{\mathrm{o}}=66.2$ and $b=0.00363$, for porosity in percent and depth in meters. ${ }^{3}$ From Colman et al. (1996b) and this paper.

${ }^{4}$ For a variety of reasons (see text), use of these ages as estimates of the ages of onset of rifting is tenuous.

times provides evidence concerning rifting history, it is difficult to transfer age estimates derived from such data to deposits in the center of the basins. For the Baikal Rift, for example, data of this kind yield estimates for the onset of rifting that vary from Oligocene to Pliocene (Hutchinson et al. 1992). Sedimentation rates derived from radiocarbon ages combined with sediment thicknesses derived from seismic-reflection data provide a more direct method (RSRM - reflection-seismic radiocarbon method-Cohen et al. 1993) of estimating the age of the rifting and (or) other basin events (Lezzar et al. 1996). The primary (and large) uncertainty in this method is extrapolation of modern sedimentation processes and their rates into the past.

Despite the fact that the main depositional basins of Lake Baikal are likely to have been dominated by turbidite deposition for much of their history, the earliest rift-related sedimentation may have been quite different, and it is unlikely that later sedimentation occurred at constant rates or in constant water depths. Using RSRM to estimate the onset of rifting from the depth to the base of the sedimentary sequence (Table 1, lines 1 and 2) is the most direct method, although the results carry large uncertainties.

As discussed above, estimates of sediment accumulation rates in the turbidite basins range from about $10-30 \mathrm{~cm} / \mathrm{kyr}$ for the Holocene to about 33-73 cm/kyr for the late Pleistocene (Ogura et al. 1992; Colman et al. 1996b), but these rates may be under-estimates of the long-term average. We infer that a sedimentation rate of about $50 \mathrm{~cm} / \mathrm{kyr}$ is a reasonable minimum long-term average accumulation rate for sediments in the turbidite basins of Lake Baikal. The Central and North basins contain an estimated minimum of 7.5 and $3.5 \mathrm{~km}$ of sediment, respectively (Hutchinson et al. 1992), which, after correcting for compaction, yield ages of 24.6 and 11.3 Ma for the beginning of accumulation of rift sediments in these basins (Table 1). Similarly, the age of the B10 horizon of Moore et al. (1997), which marks the onset of the youngest major phase of rifting, is estimated at 3.9 Ma in the North Basin (Table 1).

Using RSRM in the Selenga Delta area, the age of the base of the BDP93 drill hole is estimated to be about $0.58 \mathrm{Ma}$. However, independent age estimates by a variety of analytical methods and paleomagnetic stratigraphy for the drill-hole sediments suggest that the true age of the base of the core is about $0.66 \mathrm{Ma}$ (Kuzmin et al. 2000). Our RSRM estimate for the age of the base of the draped unit (top of the prograding units) on the Selenga Delta is $0.65 \mathrm{Ma}$ (Table 1). Using similar methods and a slightly greater thickness for the draped unit, Scholz and Hutchinson (2000) estimated an age of 0.75 Ma. Scholz and Hutchinson (2000) also traced the seismic reflection associated with the base of the draped unit through their multichannel seismic data to $82 \mathrm{~m}$ depth in the BDP93 drill hole. If this correlation is correct, then both of the RSRM estimates are likely too old, 
because the age of the base of BDP93 at $102.27 \mathrm{~m}$ is estimated to be 0.66 Ma (Kuzmin et al. 2000).

On Academician Ridge, the RSRM age of the base of the BDP96 drill holes is about 5.96 Ma. This age is about 20 percent older than the $5.0 \mathrm{Ma}$ age based on the well defined paleomagnetic stratigraphy of the drill hole (Williams et al. 1997). Some controversy has arisen over the location and age of seismic reflections in the multichannel seismic data from Academician Ridge. Moore et al. (1997) defined two prominent seismic sequence boundaries, B10 and B6, inferred to represent unconformities, in the North Basin. Although these horizons cannot be physically traced from the North Basin up onto Academician Ridge, Moore et al. (1997) correlated them to horizons on a seismic line passing through the BDP96 drill site, on the basis of seismic character and sequence. Kuzmin et al. (2000) calculated that the B10 horizon occurs at a depth of about $104 \mathrm{~m}$ at BDP96 and that it corresponds to an age of about $2.5 \mathrm{Ma}$. They found a lithologic change at that depth but no hiatus or evidence of erosion; they thus questioned whether horizon B10 is an unconformity. Alternatively, a clear unconformity appears in our high-resolution data near BDP96 at a depth of about $230 \mathrm{~m}$, the highest unconformity in the section (Fig 12), just below the $200 \mathrm{~m}$ base of BDP96. Extrapolation of the BDP96 sedimentation rate of $4 \mathrm{~cm} / 1000 \mathrm{yr}$ results in an age of $5.75 \mathrm{Ma}$ for the base of the sediments above the unconformity. The RSRM estimate for the age at this depth is 6.9 Ma (Table 1), which, like the RSRM estimate for the base of BDP96, is probably about 20 percent too large. These age estimates are sufficiently close to the RSRM age of 3.9 Ma for B10 in the North Basin (Table 1) for us to suggest that this unconformity at $230 \mathrm{~m}$, rather than the horizon at $104 \mathrm{~m}$, is equivalent to the B10 seismic sequence boundary. If correct, this inference would reconcile the drill-core stratigraphy with the deep seismic stratigraphy in the North Basin and on Academician Ridge.

\section{Importance of the Selenga Delta}

The interaction between sedimentation and tectonics on the Selenga Delta has made this prominent depositional feature distinctive. Evidence suggests that subsidence beneath the delta and surrounding areas has been extraordinary during the last several hundred thousand years. The extreme depths of the Central and South basins - the first and third deepest rift basins on earth-attest to rapid recent subsidence. The graben structure that rims the upper slope of the delta (Fig. 8) suggests flexural deformation of the deltaic sediments faster than they can be deposited.

The gross morphology of the Selenga Delta resembles classic "Gilberttype" prograding deltas deposited in much less tectonically active settings, yet much of the delta surface is draped by relatively fine-grained hemipelagic sediments. This draped sequence is underlain by deposits with distinctive, small-scale sets of sigmoidal, prograding geometry, more typical of shallower water and Gilbert-type deltas. This contrast indicates an abrupt change from shallow-water to deep-water deposition on the delta front, along with the inception of coarse-sediment bypassing of the delta, consistent with geologically recent episodes of rapid subsidence. The beginning of these episodes is indicated by the age of the base of the draped unit, $650 \mathrm{ka}$ (Table 1). This estimate is older than that of Romashkin et al. (1997), who based their estimate of $150 \mathrm{ka}$ on sedimentation rates derived from ${ }^{210} \mathrm{~Pb}$ data from short cores (Edgington et al. 1991). The ${ }^{210} \mathrm{~Pb}$-derived rates are considerably higher than those derived from radiocarbon dating of longer cores (Colman et al. 1996b), probably because of compaction of the very water-rich surficial sediments.

Rapid subsidence and active, upslope-facing fault scarps have led to the incision of channels and canyons through which most coarse-grained and mass-flow sediments bypass the delta front. Consequently, coarse sediment feeds the huge subaqueous fans at the toe of the delta, leading into the Central and South basins. The effects of the combination of rapid subsidence and active faulting demonstrate the degree to which tectonics has influenced the morphology and depositional patterns of this massive feature.

The evidence for rapid subsidence during the last $650 \mathrm{ka}$ discussed above suggests that Lake Baikal may be in an unusual situation, perhaps an end member of rift-basin configurations. Despite abundant sediment supply and relatively rapid sedimentation rates, and despite multiple cycles of glaciation, subsidence seems to have far outstripped sedimentation in the major basins of the lake over the last few hundred thousand years. At a sedimentation rate of $50 \mathrm{~cm} / \mathrm{kyr}$, and from the compaction correction in Table $1,385 \mathrm{~m}$ of sediment would accumulate in one million years. Thus, subsidence rates would have to be substantially greater than $0.385 \mathrm{~mm} / \mathrm{yr}$ in order to maintain great water depths in the basins of Lake Baikal. Because it is difficult to estimate the subsidence rate of rift basins independently of their sediments, it is difficult to evaluate this rate of subsidence, other than to note that it is a minimum value. Also, subsidence rates may vary considerably between different basins within the rift.

Subsidence exceeding sedimentation during the last $650 \mathrm{ka}$ has led to formation of the first (Central Basin) and third (South Basin) deepest lacustrine rift basins known on earth. Only Lake Tanganyika is comparable in depth. Relative uplift of the outlet may have contributed to deepening of the lake, but considering the variation in the depths of the different basins and the time interval involved, subsidence of the basins appears to be the first-order control. It seems unlikely that subsidence can outpace sedimentation for long periods of time, so rates of subsidence and sedimentation were probably closer for most of the history of the lake. If so, the present extreme depth of the lake is unusual.

\section{ACKNOWLEDGMENTS}

We thank the numerous shipboard scientists and crew members of the R.V. Vershchagin for assisting with the collection of data. Prof. M. Kuzmin and Prof. M. Grachev, directors of the Institute of Geochemistry and the Limnological Institute, respectively, in Irkutsk, and P. Hearn of the U.S. Geological Survey provided a vast amount of logistical and organizational assistance. D. Foster processed and plotted the seismic profiles and J. Zwinakis drafted the figures. Helpful reviews were provided by M. de Batiste, W.P. Dillon, D.R. Hutchinson, T.C. Johnson, and R.N. Oldale. This study was supported by the USGS Global Change and Climate History Program and the Limnological Institute of the Siberian Branch of the Russian Academy of Sciences. The Baikal Drilling Project was also supported by the U.S. National Science Foundation (grant EAR-9119537) and by the Japanese Association for Baikal International Research Programs.

\section{REFERENCES}

AgaR, S.M., AND KLITGORD, K.D., 1995, Rift flank segmentation, basin initiation and propagation: A neotectonic example from the Baikal Rift: Journal, Geological Society of London, v. 152 , p. $849-860$.

Antipin, V., AND 52 OTHERs, 2001, The new BDP-98 600-m drill core from Lake Baikal: A key late Cenozoic sedimentary section in continental Asia: Quaternary International, v. 80-81, p. 19-36.

Back, S., De Batist, M., Kirillov, P., Strecker, M.R., and Vanhauwaert, P., 1998, The Frolikha fan: A large Pleistocene glaciolacustrine outwash fan in northern Lake Baikal, Siberia: Journal of Sedimentary Research, v. 68, p. 841-849.

Back, S., De Batist, M., Strecker, M.R., and Vanhauwaert, P., 1999, Quaternary depositional systems in northern Lake Baikal, Siberia: Journal of Geology, v. 107, p. 1-12.

BaKsi, A.K., Hsu, V., McWilliams, M., And Farrar, E., 1992, ${ }^{40} \mathrm{Ar} /{ }^{39} \mathrm{Ar}$ dating of the BrunhesMatuyama geomagnetic field reversal: Science, v. 256, p. 356.

BDP Members, 1997a, Preliminary results of the first drilling on Lake Baikal, Buguldeika site, southeastern Siberia: Quaternary International, v. 37, p. 3-17.

BDP Members, 1997b, Continuous Paleoclimate record recovered for last 5 million years: EOS, Transactions, American Geophysical union, v. 78, p. 597, 601, 604

Bezrukova, E.V., Bogdanov, Y.A., Williams, D.F., Granina, L.Z., Grachev, M.A., Ignatova, N.V., Karabanov, E.B., Kuptsov, V.M., Kurylev, A.V., Letunova, P.P., Likhoshvay, E.V., Chernyaeva, G.P., Shimaraeva, M.K., and Yakushin, A.O., 1991, A dramatic change of the ecological system of Lake Baikal in the Holocene: Akademiya Nauk SSSR, Doklady, v. 321, p. 1032-1037.

CARTER, S.J., and Colman, S.M., 1994, Biogenic silica in Lake Baikal sediments: Results from 1990-1992 American cores: Journal of Great Lakes Research, v. 20, p. 751-760.

Ceramicola, S., Rebesco, M., De Batiste, M., and Khlystov, O., 2001, Seismic evidence of small-scale lacustrine drifts in Lake Baikal (Russia): Marine Geophysical Researches, v. 22, p. 445-464. 
Cohen, A.S., Soreghan, M.J., and Scholz, C.A., 1993, Estimating the age of formation of lakes: An example from Lake Tanganyika, East African Rift system: Geology, v. 21, p. 511-514.

Colman, S.M., 1998, Water-level changes in Lake Baikal, Siberia: Tectonism versus climate: Geology, v. 26, p. 531-534.

Colman, S.M., Carter, S.J., Hatton, J., and Haskel, B.J., 1994b, Cores collected by the U.S. Geological Survey in Lake Baikal, Siberia: Visual descriptions, photographs, X-radiographs, bulk density, and grain size: U.S. Geological Survey, Open-File Report 94-445, 122 p.

Colman, S.M., Foster, D.S., AND HatTon, J., 1996a, High-resolution seismic-reflection surveys of Lake Baikal, Siberia, 1990-1992: U.S. Geological Survey, Open-File Report 96-274, 21 p.

Colman, S.M., Jones, G.A., Rubin, M., King, J.W., Peck, J.A., And Orem, W.H., 1996b, AMS radiocarbon analyses from Lake Baikal, Siberia: Challenges of dating sediments from a large, oligotrophic lake: Quaternary Science Reviews, v. 15, p. 669-684.

Colman, S.M., Nichols, D.R., Bardardinov, A.A., Foster, D.S., O'Toole, J.K., and Parolski, K.E., 1994a, High-resolution seismic-reflection surveys of Lake Baikal, Siberia, 1990-1992: Methods and examples: International Project on Paleolimnology and Late Cenozoic Climate (IPPCCE) Newsletter, v. 7, p. 43-48

Colman, S.M., Peck, J.A., Karabanov, E.B., Carter, S.J., Bradbury, J.P., King, J.W., and Williams, D.F., 1995, Continental climate response to orbital forcing from biogenic silica records in Lake Baikal, Siberia: Nature, v. 378, p. 769-771.

Edgington, D.N., Klump, J.V., Robbins, J.A., Kusner, Y.S., Pampura, V.D., and Sandimirov, I.V., 1991, Sedimentation rates, residence times and radionuclide inventories in Lake Baikal from ${ }^{137} \mathrm{Cs}$ and ${ }^{210} \mathrm{~Pb}$ in sediment cores: Nature, v. 350, p. 601-604.

Edgington, D.N., Robbins, J.A., Colman, S.M., Orlandini, K.A., and Gustin, M.-P., 1996 Uranium-series disequilibrium, sedimentation, diatom frustules, and paleoclimate change in Lake Baikal: Earth and Planetary Science Letters, v. 142, p. 29-42.

Faulkner, K.K., Measures, C.I., Herbelin, S.E., Edmond, J.M., and Weiss, R.F., 1991, The major and minor element geochemistry of Lake Baikal: Limnology and Oceanography, v. 36 , p. 413-423.

Granina, L.Z., Grachev, M.A., Karabanov, E.B., Kuptsov, V.M., Shimaraeva, M.K., and WiLLiAms, D.F., 1993, Accumulation of biogenic silica in bottom sediments of Baikal: Russian Geology and Geophysics, v. 34, p. 126-135.

Hohmann, R., Kipfer, R., Peeters, F., Piepke, G., and Imboden, D.M., 1997, Processes of deepwater renewal in Lake Baikal: Limnology and Oceanography, v. 42, p. 841-855.

Hutchinson, D.R., Golmshtok, A.J., Zonenshain, L.P., Moore, T.C., Scholz, C.A., and KlitGORD, K.D., 1992, Depositional and tectonic framework of the rift basins of Lake Baikal from multichannel seismic data: Geology, v. 20, p. 589-592.

Karabanov, E.B., and Fialkov, V.A., 1987, Morphology of Baikal Canyons (in Russian): Akademiya Nauk SSSR, Sibirskoe Otdolovic, 104 p.

KatZ, B.J., 1990, Controls on the distribution of lacustrine source rocks through time and space, in Katz, B.J., Lacustrine Basin Evolution-Case Studies and Modern Analogs: American Association of Petroleum Geologists, Memoir 50, p. 61-76.

Kozhov, M., 1963, Lake Baikal and Its Life: The Hague, Netherlands, Dr. W. Junk Publishers, $339 \mathrm{p}$.

Kuzmin, M.I., Karabanov, E.B., Prokopenko, A.A., Gelety, V.F., Antipin, V.S., Williams, D.F., AND GvozdKov, A.N., 2000, Sedimentation processes and new age constraints on rifting stages in Lake Baikal: Results of deep-water drilling: International Journal of Earth Science, v. 89 , p. $183-192$.

Kuzmin, M.I., Williams, D.F., Logatchev, N.A., Colman, S., Khakhaev, B.N., Kawai, T. Hearn, P., Horie, S., Pevzner, L.A., Bukharov, A.A., and Fialkov, V.A., 1993, The Baika Drilling Program: Tasks, proceedings, solving process problems: Russian Geology and Geophysics, v. 34, p. 3-11.

Lake Baikal Paleoclimate Project Members, 1992, Initial results of the joint Russian-American project on the paleoclimatic record of Lake Baikal, southeastern Siberia: EOS, Transactions of the American Geophysical Union, v. 73, p. 457-462.

Lezzar, K.E., Tiercelin, J.-J., DeBatist, M., Cohen, A.S., Bandora, T., Van Rensbergen, P. Le Turdu, C., Mifundu, W., and Klerkx, J., 1996, New seismic stratigraphy and Late Tertiary history of the North Tanganyika basin, East Africa Rift system, deduced from multichannel and high-resolution reflection seismic data and piston core evidence: Basin Research, v. 8, p. 1-26.

Logatchev, N.A., and Florensov, N.A., 1978, The Baikal system of rift valleys: Tectonophysics, v. 45 , p. $1-13$.
Mats, V.D., 1993, The structure and evolution of the Baikal rift depression: Earth-Science Reviews, v. 34, p. 81-118.

Mats, V.D., Khlystov, O.M., De Batist, M., Ceramicola, S., Lomonosova, T.K., and KlimanSKY, A., 2000, Evolution of the Academician Ridge accomodation zone in the central part of the Baikal Rift, from high-resolution reflection seismic profiling and geological field investigations: International Journal of Earth Science, v. 89, p. 229-250.

Moore, T.C., Klitgord, K.D., Golmshtor, A.J., and Weber, E., 1997, Sedimentation and subsidence patterns in the Central and North Basins of Lake Baikal from seismic stratigraphy: Geological Society of America, Bulletin, v. 109, p. 746-766.

Nelson, C.H., Karabanov, E.B., and Colman, S.M., 1995, Late Quaternary turbidite systems in Lake Baikal, Russia, in Pickering, K.T. Ricci Lucchi, F., Smith, R., Hiscott, R.N., and Kenyon, N., An Atlas of Deep-Water Environments: London, Chapman \& Hall, p. 29-33. Nelson, C.H., Karabanov, E.B., Colman, S.M., and Escutia, C., 1999, Tectonic and sedimentsupply control of deep rift lake turbidite systems: Lake Baikal, Russia: Geology, v. 27, p. 163-166.

Nelson, C.H., Maldonado, A., Barber, J.H., JR., And Alonso, B., 1991, Modern sand-rich and mud-rich siliciclastic aprons, alternative base-of-slope turbidite systems to submarine fans, in Weimer, P., and Link, M.H., Seismic Facies and Sedimentary Processes of Modern and Ancient Submarine Fans: Berlin, Springer-Verlag, p. 171-190.

Nelson, C.H., Meyer, A.W., Thor, D., And Larsen, M., 1986, Crater Lake, Oregon: A restricted basin with base-of-slope aprons of nonchannelized turbidites: Geology, v. 14, p. 238-241.

Ogura, K., Ishiwatari, R., And Nakamura, T., 1992, A preliminary report on ${ }^{14} \mathrm{C}$ ages of a 4.6 $\mathrm{m}$ long core sample of Lake Baikal: International Project on Paleolimnology and Late Cenozoic Climate (IPPCCE) Newsletter, v. 6, p. 123-124.

Olsen, P.E., Kent D.V., Cornet B., Witte W.K., and Schlische R.W., 1996, High-resolution stratigraphy of the Newark rift basin (early Mesozoic, eastern North America): Geological Society of America, Bulletin, v. 108, p. 40-77.

Peck, J.A., King, J.W., Colman, S.M., and Kravchinsky, V.A., 1994, A rock-magnetic record from Lake Baikal, Siberia: Evidence for late Quaternary climate change: Earth and Planetary Science Letters, v. 122, p. 221-238.

Qiu, L., Williams, D.F., Gvorzskov, A., Karabanov, E., and Shimaraeva, M., 1993, Biogenic silica accumulation and paleoproductivity in the northern basin of Lake Baikal during the Holocene: Geology, v. 21, p. 25-28

Romashinin, P.A., Karabanov, E.B., and Williams, D.F., 1997, Sedimentation history of the Selenga Delta, Lake Baikal: Simulation and interpretation: Journal of Paleolimnology, v. 18, p. 179-186.

Scholz, C.A., AND Hutchinson, D.R., 2000, Stratigraphic and structural evolution of the Selenga Delta accommodation zone, Lake Baikal Rift, Siberia: International Journal of Earth Science, v. 89 , p. $212-228$

Scholz, C.A., Moore, T.C., Hutchinson, D.R., Golmshtok, A.J., Klitgord, K.D., And KurotchKIN, A.G., 1998, Comparative sequence stratigraphy of low-latitude versus high-latitude lacustrine rift basins: seismic data examples from the East Africa and Baikal rifts: Palaeogeography, Palaeoclimatology, Palaeoecology, v. 140, p. 401-420.

Sclater, J.G., And Christie, P.A.F., 1980, Continental stretching: An explanation of post-MidCretaceous subsidence in the central North Sea basin: Journal of Geophysical Research, v. 85, p. 3711-3739.

TAliev, S.D., AND Bardardinov, A.A., 1993, Conditions of accumulation of Pleistocene deposits of southern Baikal: Russian Geology and Geophysics, v. 34, p. 28-40.

Weiss, R.F., Carmack, E.C., and Koropalov, V.M., 1991, Deep water renewal and biological production in Lake Baikal: Nature, v. 349, p. 665-669.

Williams, D.F., Colman, S.M., Hearn, P.P., Jr., Khakhaev, B.N., Kuzmin, M., Grachev, M., and Karabanov, E., 1992, The Baikal Drilling Project: American-Russian paleoclimatic research at Lake Baikal, the world's deepest lake (abstract): EOS, Transactions of the American Geophysical Union, v. 73, p. 149

Williams, D.F., Kuzmin, M.I., Prokopenko, A.A., Karabanov, E.B., Khursevich, G.K., and Bezrukova, E.V., 2001, The Lake Baikal drilling project in the context of a global lake drilling initiative: Quaternary International, v. 80-81, p. 3-18

Williams, D.F., Peck, J., Karabanov, E.B., Prokopenko, A.A., Kravchinsky, V., King, J., and Kuzmin, M.I., 1997, Lake Baikal record of continental climate response to orbital insulation during the past 5 million years: Science, v. 278, p. 1114-1117.

Received 24 June 2002; accepted 17 April 2003. 